\title{
LA VIDA CAMPESINA EN MURO DE AGUAS EN LA BAJA EDAD MEDIA
}

\author{
Pedro Pérez Carazo \\ IES Escultor Daniel. Logroño \\ Centro Asociado de la UNED de La Rioja
}

\section{Introducción}

Se localiza la villa de Muro de Aguas en la sierra riojabajeña, en un pequeño valle de la cabecera del río Linares, de tierras altas y de abruptas calizas, con un clima mediterráneo de veranos largos, calurosos y secos, y de tendencia continental. Alejada de las influencias atlánticas, las precipitaciones van a ser más bajas que en el sector occidental camerano y las temperaturas, por el contrario, más elevadas. Estas condiciones físicas y climáticas hacen que su término jurisdiccional ofrezca un suelo inapropiado para el desarrollo de la agricultura y abundantes pastizales y recursos forestales, que han permitido a sus habitantes mantener una numerosa cabaña ganadera, ya que los -relativamente- suaves inviernos no impiden el pastoreo, a no ser que un elevado número de cabezas agote el pasto y los recursos forestales en invierno. Las actividades agrícolas y ganaderas han sido complementarias y destinadas a la subsistencia, no a la comercialización, hasta los años 60 del siglo XX.

No se encuentra bien situada la villa respecto a las principales vías de comunicación de la región, a través de las que se desarrollan los circuitos comerciales más importantes: el Valle del Ebro, donde se sitúa la ciudad de Calahorra, que articula el territorio, ya que es el principal centro de población -y de demanda-, sede episcopal y el centro político de referencia en la zona, al ser lugar de residencia del prestamero del rey hasta finales del siglo XIV; y, en segundo lugar, el Valle del Cidacos, que une el Valle del Ebro con la Meseta a través del paso de Enciso. Esta pequeña villa del Alto Linares aparece en la documentación el 12 de junio de 1369, cuando Enrique II de Castilla se la entrega en donación -junto con su aldea de Entrambasaguas- a Juan Ramírez de Arellano I para pagarle al noble navarro el importante apoyo político y mili- 
tar que le había prestado en la guerra contra su hermanastro, el rey Pedro I de Castilla, a quien acababa de derrotar y dar muerte en Montiel; y, de este modo, se integraba en un gran señorío feudal castellano ${ }^{1}$.

La realidad económica y social a la que responden, tanto la concentración del hábitat en estos dos núcleos como el paisaje agrario adaptado a la misma y que se refleja en la documentación bajomedieval, se ha formado ya para estas fechas de mediados del siglo XIV; y las familias campesinas que los habitaban vivían de los recursos que obtenían de la explotación agrícola familiar, privada, y del aprovechamiento de los términos comunales y comuneros de su concejo, ganadero y forestal, fundamentalmente, que Ilevaban a cabo comunalmente según sus usos y costumbres, es decir, según el modo de explotación tradicional de esos espacios hasta esa fecha². Pero el aumento demográfico sostenido que había impulsado un intenso proceso roturador en la región, bien documentado desde la segunda mitad del siglo XII y primera mitad del XIII en el Valle del Cidacos, el Valle de Ocón y el Camero Viejo, hacía necesario, por una parte, reorganizar el espacio de uso agrícola y, por otra, regular el aprovechamiento ganadero y forestal de sus términos, haciéndolos compatibles.

Desde finales del siglo XIII, la excesiva presión antrópica sobre el medio necesitaba ya unos límites para no agotar totalmente los recursos. Los concejos de Arnedo y Herce, desde 1263, debían regular el aprovechamiento ganadero y forestal de sus términos comuneros, acotar ciertos espacios -las dehesas, para crear reservas de pastos y arbolado-, y los concejos de Ocón y de Jubera, en 1261, prohibían realizar más presuras y también creaban dehesas, debido a la finalización de la intensa colonización agraria de la época precedente ${ }^{3}$. Y restringían el aprovechamiento de estos terrenos a los vecinos de sus concejos, prohibiendo a los de fuera aprovecharlos, ya que en los espacios de uso comunal y comunero crían y pastoreaban sus pequeños rebaños de ovejas, cabras, ganados de labor y sus piaras de cerdos, de los que obtenían unos recursos imprescindibles para subsistir.

Un siglo después, tras las crisis agrarias y la regresión demográfica, especialmente graves entre 1343 y 1351, la sociedad castellana había iniciado

1. DIAGO HERNANDO, M. Implantación territorial del linaje Arellano en tierras Cameroriojanas a fines de la Edad Media, pág. 74.

2. Los bienes comunales son propiedad de todos los vecinos de una villa en su conjunto y, por ello, están sujetos a un aprovechamiento colectivo y su utilización regulada por el concejo; los comuneros son aquellos terrenos y bienes comunales situados en el término de un concejo y cuyo aprovechamiento colectivo llevan a cabo tanto los vecinos del concejo en cuyo término se encuentran como los vecinos de los concejos con los que éstos hubieran llegado a un acuerdo para la utilización conjunta de los mismos.

3. PÉREZ CARAZO, P. Santa María de Herce y su abadengo en la Edad Media, 425-456 (HERCE), y Colección diplomática medieval de Santa María de Herce y su abadengo en la Edad Media, $35(\mathrm{CDH})$. 
-sobre todo, desde comienzos del siglo XV- un proceso de expansión demográfica y de crecimiento económico continuos ${ }^{4}$, y actuaba sobre el entorno de una forma más agresiva. El hábitat se concentra en la villa de Muro de Aguas y en su aldea de Emtrambasaguas, abandonando otros asentamientos peor situados -el que hubiera en los Villares-, y el espacio productivo se especializa, dividiéndose en pagos, es decir, en espacios de dedicación agrícola homogénea: cereal, olivar, huertos, viñas, etc..., cuyo uso y utilización regulan los concejos.

La caída demográfica de mediados del siglo XIV había estimulado el aumento de la cabaña ganadera y, ahora, con la recuperación demográfica, se hace más precario el equilibrio entre la dedicación agrícola y el aprovechamiento ganadero y forestal del espacio y llega a peligrar esa forma de explotación tradicional del espacio agrícola y del monte, es decir, los usos y costumbres de las comunidades campesinas arriba mencionados; y los concejos, que son las instituciones encargadas de regular el aprovechamiento del término concejil, se ven en la necesidad de ponerlos por escrito, de legalizarlos plenamente e imponer fuertes multas a quienes no los respeten. Se trata de normas concretas elaboradas para regular cuestiones específicas relativas al aprovechamiento económico de sus territorios y que preocupan en esos momentos a sus vecinos, ya que, si éstos no compatibilizan el aprovechamiento agrícola y ganadero de los espacios de producción, y no regulan el aprovechamiento ganadero y forestal del monte, pueden agotar estos recursos para siempre.

\section{Acuerdos}

Tras las dificultades de finales del siglo XIII y, sobre todo, tras la crisis de mediados del siglo XIV, las condiciones políticas, jurídicas y, sobre todo, las económicas y sociales, en que se desenvolvía la vida de los habitantes de Muro de Aguas, ahora vasallos del Señor de los Cameros, cambian drásticamente y hacen urgente y necesaria a su concejo la actualización, también, de esta normativa de carácter supralocal -que recogía los usos y costumbres tradicionales mediante los que regulaban sus vecinos el aprovechamiento ganadero y forestal de su término-, haciendo necesario celebrar reuniones periódicas entre sus procuradores y los de los concejos limítrofes para actualizarla y acomodarla a las necesidades específicas de sus vecinos en cada momento concreto, apaciguar las disputas que existen entre ellos y coordinar acciones de interés común, reuniones que reciben también el nombre de «juntas de valle» o de «comunidades de valle» ${ }^{5}$.

4. GARCÍA DE CORTÁZAR, J. Á. La época medieval, pág. 327.

5. Este recurso jurídico es el más empleado -en general- en los reinos cristianos peninsulares durante la Baja Edad Media. ARGENTE DEL CASTILLO OCAÑA, C. La ganadería medieval andaluza. Siglos XIII-XVI (reinos de Jaén y Córdoba), II, 440-441. 


\subsection{Con el concejo de Enciso}

Conocemos varios acuerdos alcanzados en la Baja Edad Media por el concejo de Muro de Aguas en estas reuniones. El primero, el 29 de septiembre de 1373, en la junta que celebran sus representantes con los del concejo de Enciso en el lugar señalado para ello: el nogal de Totico.

En primer lugar, regulan el pastoreo en sus términos concejiles y acuerdan mantener en vigor entre ellos una mancomunidad de pasto de las que se denominan soles y que consistían en que los vecinos de cada concejo podían apacentar sus ganados en los terrenos comuneros situados en el término del otro concejo de día y regresar con ellos a su término concejil a pasar la noche en sus majadas -a amajadar, como se indica en la documentación- antes de la puesta del sol. Se trata de los rebaños de ganado estante que crían los vecinos de ambos concejos, pequeños y diversos, no especializados, de ovejas, cabras, mulos, asnos, etc..., y que pastorean en los comunales de su término concejil y en los comuneros de éste en los limítrofes sin pagar ningún impuesto de aprovechamiento de hierbas por ello y simultaneando perfectamente ambas actividades. Si la cabaña -un rebaño de más de treinta cabezas- de ovejas y cabras de los vecinos de Muro de Aguas pasa la noche -se alberga- en el término concejil de Enciso pagará tres maravedís de multa; y viceversa ${ }^{6}$.

Protegen el espacio destinado a un uso agrícola permanentemente de las intromisiones del ganado: las dehesas «de pan, de vino o de restrojos» y la Dehesa de los Huertos, que está alrededor del caserío de la aldea de Entrambasaguas. Lo que nos indica que en estos concejos el espacio productivo estaba ya en estas fechas organizado en diferentes zonas de dedicación agrícola homogénea -es decir, en los pagos arriba citados-. Los más importantes eran los cerealistas, las dehesas de pan, que eran espacios abiertos que el concejo organizaba en distintos sectores, denominados hojas, y que se cultivaban por el sistema de año y vez. Los campesinos dividían el pago en dos o más hojas y debían sembrar cada año en una de ellas y dejar la otra, o las otras, en barbecho. Es decir, que todos ellos debían guardar la misma rotación de cultivos y sembrar en la misma hoja, pues no podían cultivar algunas parcelas fuera del área sembrada, ni intercalar otros cultivos diferentes, porque la división en hojas del terrazgo cerealista sería entonces ineficaz. El aprovechamiento agrícola y el ganadero del pago debían estar perfectamente imbricados, sincronizados, y el concejo era la institución encargada de obligar a los campesinos a realizar las labores de arar, sembrar, cosechar y pastorear -es decir, a vedar y desvedar el pago-, al mismo tiempo, para defender mejor la hoja sembrada de las entradas

6. «E si la cabaña de las dichas ovejas e cabras de los vezinos de ençiso e de sus aldeas alvergaren de noche en término de Muro que aya de coto tres maravedís; e la cabaña de los vezinos de Muro que aya esta mesma pena si alvergare en término de Ençiso» (Doc. 1). 
de los ganados y permitir que éstos pastasen en la que no estaba, porque los animales eran imprescindibles para satisfacer las necesidades de leche, carne, etc..., de los campesinos, además de que el ciemo que proporcionaban -junto al estiércol de los animales de labor- era el único abono con el que contaban los labradores para fertilizar el terreno ${ }^{7}$. Cuando intercalaban otros cultivos dentro del terrazgo cerealista debían, obligatoriamente, cercarlos, para no romper el sistema de rotación bienal de todo el pago - de año y vez- y no perjudicar tanto el aprovechamiento cerealista del pago como el aprovechamiento ganadero de los rastrojos y entrepanes -si los había-, pues el terreno sembrado volvía a tener un uso ganadero una vez recogida la cosecha de la hoja cultivada.

En ellos, la hoja que se sembraba estaba protegida de las intromisiones del ganado desde que se sembraba hasta que se recogía de ella la cosecha; una vez recogida, pasaba a tener un aprovechamiento ganadero $y$, por lo tanto, un uso comunal. Y las hojas que quedaban en barbecho, estaban vedadas desde el primero de marzo, cuando se araban para sembrar en ellas las leguminosas y los cereales de primavera y para preparar la siembra del año próximo, al quince de agosto, que es cuando se recogía la cosecha y todo el pago quedaba para pasto común de los ganados de los vecinos de ambos concejos ${ }^{8}$. Son las mismas fechas hasta las que están vedados los rastrojos en la Villa y Tierra de Yanguas, en el Valle del Cidacos y en el Camero Viejo.

En segundo lugar, regulaban meticulosamente el ramoneo, el corte de leña y la montanera, es decir, el aprovechamiento económico del monte y el bosque de sus comuneros. El ramoneo de chopos, olmos, encinas, marojos, quejigos, etc..., consiste en cortar el ramón -las ramas delgadas y verdes de estos árboles- para alimentar con ellas al ganado cuando el pasto se agota en los largos y secos veranos de la zona, y en invierno, cuando la nieve permanece en el suelo y no deja a los animales comer la hierba, limitando su práctica a los vecinos de Muro de Aguas en el término jurisdiccional de su concejo y a los de Enciso en el suyo. Si los vecinos de Muro de Aguas ramoneaban en el comunero situado en el término jurisdiccional de Enciso debían satisfacer un impuesto de leñas y pagar unas tasas proporcionales a la cantidad que cortasen a los oficiales de este concejo; y viceversa ${ }^{9}$.

7. GARCÍA FERNÁNDEZ, J. Campos abiertos y campos cercados en Castilla la Vieja, págs. 122-125.

8. Este parece ser el uso y costumbre seguido para regular el aprovechamiento de los pagos cerealistas en toda la región desde la segunda mitad del siglo XIII, tal como se indicaba, en 1272 , en una sentencia arbitral que regulaba el aprovechamiento de un comunero entre los concejos de Santurdejo y Ayuelas: «e los de Santurdejo que lavren y panieguen la Solana que dicen de Yecolea e la de Vagan Dicoturri, así como las aguas vierten, amas a dos, con los frontales, como descenden contral río en tal guisa que, el año que fuesse pan, que las cierren; e, el pan alçado, que pascan comunalmente los unos e los otros» (CDMR, IV, 319).

9. Si los vecinos de Muro de Aguas cortan ramón en el comunero situado en el término concejil de Enciso para una cabaña de ovejas y cabras, pagarán ocho maravedís de multa; si el 
El aprovechamiento de la leña seca que precisasen como combustible para sus viviendas y la madera que necesitasen para fabricar sus utensilios de trabajo: aladros, trillos, palas, horcas, escriños, cestas, mangos de mazas, martillos, hachas y destrales, azadas, cedazos, etc..., era libre. En cambio, debían pagar ciertos arbitrios para poder cortar leña verde en el comunero situado en el término jurisdiccional del otro concejo y llevarla al suyo: por cortar hayas, robles o encinas, por el pie, pagan 4 maravedís; por el cornal-aún se denomina hoy con esta palabra a la rama grande del árbol que sale del tronco y da forma a la copa de éste- un maravedí. Por la carga -la que puede llevar en un animal- un maravedí; por la carga de ramón 15 dineros, por el haz -una gavilla- de ramón 5, por el palanco -es decir, por un magazo, por una vara o estaca larga y gruesa, rígida, que no se dobla- pagarán sólo 3.

El aprovechamiento del fruto de los árboles, de la fruiz del bosque -así lo denominaban en el Camero Viejo-, para cebar a los animales -sobre todo, a los cerdos- con la bellota de encinas y robles -las landes- y con los hayucos, hoyetas $\mathrm{u}$ hoyes - hoes indica en el documento- de las hayas. Los vecinos de ambos concejos pueden aprovechar con sus piaras de cerdos los montes comuneros de sus términos sin pena alguna si el fruto ha caído al suelo, es decir, sin que los animales coman las bellotas directamente de los árboles -los bueyes y las vacas lo hacen con suma facilidad- y sin varearlos para que caigan; si los varean, pagarán tres maravedís de multa y perderán el fruto que hayan cogido. Es decir, permiten consumir la bellota cuando ya ha madurado y sirve para alimentar los cerdos en invierno. Si varean los árboles y la cogen antes, además de que agotan el alimento para el invierno, que es cuando realmente lo necesitan, sufre muchísimo más el árbol. Las bellotas y landes las desvedaban, como en el Camero Viejo y en la Villa y Tierra de Soria, desde el día de San Martín -el 11 de noviembre-, como indican en las juntas entre Muro de Aguas y Préjano, en 1390 y $1450^{10}$. Y pueden aprovisionarse de leña y llevar a pastar la bellota a sus piaras de cerdos libremente en todos los otros montes menores de sus términos.

ramón cortado es para menos de treinta cabezas de este ganado, pagarán de multa, por cada «res, dos meajas de las que fazen seis un dinero»; si es para bueyes y vacas, por «cada res, dos dineros, e la vaca que saque su fijo que mamare», es decir, que por el ternero que aún mamase de su madre y que estuviese con ella no pagarán multa.

10. «En quanto altañe a la fruiz del Verduquedo, que, si la huviere, que sea visto por dos buenos hombres de Robles y otros dos buenos hombres de La Santa y, si fallaren que hay fruiz que deve ser guardada, que la guarden desde el día de San Miguel adelante fasta el día de San Martín; y que embíen carta de viedo, si fruiz hubiere, desde el día de San Miguel adelante, quando quisieren; y que, fasta que emvíen la dicha carta de viedo, que no lo ayan por vedado» $(C D H$, 284). También en la Villa y Tierra de Soria, en el siglo XVI, se vedaba, «por costumbre inmemorial, desde el día de Santa Cruz de septiembre hasta el día de San Martín de noviembre, el resto del año estaba desvedada». DÍEZ SANZ, E. La Tierra de Soria. Un universo campesino en la Castilla del siglo XVI, pág. 114. 
Que ambos concejos necesiten regular tan minuciosamente el ramoneo, el corte y la montanera -además de que les permitía obtener unos ingresos nada desdeñables-, nos indicaría que sus vecinos han ido cortando, ahuecando -y degradando- progresivamente el monte mayor de encinas y robles de gran porte, y creando en su lugar estos montes menores, huecos, de encinas y carrascas más rastreras, en los que aprovisionarse de leña, ramón y montanera. Por eso prohibían aprovecharlos libremente a sus vecinos y limitaban estas prácticas, para evitar el agotamiento de estos encinares y rebollares degradados, tratando de mantener un equilibrio entre la existencia de amplios espacios de montes mayores y menores en sus términos jurisdiccionales y la cabaña ovina estante $-y$ los ganados de labor y de cerda- de los vecinos de estos concejos, pues talando sus bosques harían desaparecer la cubierta vegetal que servía de soporte al arbolado y a los pastizales ${ }^{11}$. La misma preocupación por restringir el aprovechamiento forestal y proteger los espacios acotados, las dehesas -reservas de pastos y arbolado-, que expresaban ya en 1263 los concejos de Arnedo y Herce, y en 1272 los representantes de los concejos de Santurdejo y Ayuelas ${ }^{12}$, lo que es un síntoma evidente de que, desde estas fechas, estos recursos escaseaban.

Los guardas encargados de vigilar que estos acuerdos se cumplan serán deheseros jurados por ambos concejos y puestos en su cargo por un año. Si alguno defendía la prenda que éstos le tomaban y no pagaba la multa correspondiente que le imponían por no respetar la normativa recogida en estos acuerdos, podían ir al concejo de donde era vecino quien había causado el daño y exigir a sus oficiales que le pagasen la multa doblada; y, si éstos no se la pagaban, desde que les fue requerido su pago en veinte días, se la podían cobrar de bienes propios de dicho concejo o de cualquiera de sus vecinos. Que los respectivos concejos, en último término, se responsabilicen del cumplimiento de estos acuerdos por sus vecinos, y se comprometan asimismo a pagar la infracción cometida por alguno de ellos, fomentaría, qué duda cabe, un fuerte sentimiento de pertenencia a la comunidad de todos ellos, tal como ocurría en el Valle del Cidacos y en el Camero Viejo en fechas algo posteriores ${ }^{13}$.

11. Se denomina menor al monte bajo, no espeso sino hueco, poblado de agrupaciones aisladas de brotes de las cepas, y de arbustos, como estrepas, ulagas, etc. Los árboles se podaban a dos o tres palmos del suelo para formar arbustos o árboles bajos, achaparrados, que se podan cada cinco o seis años para aprovecharlos para obtener leñas y ramón. JORDANA Y MORERA, J. Algunas voces forestales y otras que guardan relación con las mismas, págs. 165-166.

12. $C D H, 35$ y $C D M R, I V, 319$ «E los de Santurdejo que tajen en toda la dehesa en tal guisa que non tajen de raýz, mas que desmochen, de guisa que non destruyan la dehesa e que sea guardada; e los de Hayuela non tajen en toda la dehesa sino como sobredicho es».

13. En todos los casos, los alcaldes, guardas o jurados yunteros, encargados de vigilar el cumplimiento de los acuerdos de las yuntas, son nombrados conjuntamente por los concejos que los suscriben. Ya en 1263, en los acuerdos entre Arnedo y Herce $(C D H, 35)$; y en $C D H, 86$ (1412), 107 (1423), 112 (1430). 
Confirmaban asimismo el uso y costumbre que tenían los vecinos de Muro de Aguas y Enciso de poder entrar con sus ganados a sus comuneros por los términos de Préjano, San Pedro Manrique y Vea ${ }^{14}$. Esto se conocía en la práctica ganadera como derecho de traspacimiento, es decir, derecho de paso por determinados lugares de los términos de estos concejos para ir a apacentarlos a sus comuneros, pasando, paciendo y bebiendo, por ellos, con sol, como indica el texto del acuerdo. También se reconocían ese uso y costumbre -unos a otros-, en 1445, los concejos de la Villa y Tierra de Yanguas y San Román de Cameros, Rabanera, Ajamil y Torremuña ${ }^{15}$. Y se ofrecían ayuda mutua y garantía de que podían comprar y vender libremente cuantas provisiones necesitasen los unos en los términos del otro concejo como si fuera el suyo, sin pagar portazgo alguno por ello.

En la junta que celebran el 8 de abril de 1392, denuncian que los alcaides de los castillos que están enclavados en sus términos jurisdiccionales les cobran a sus vecinos "carnero e borra de pasaje e castellería, de cada cabaña de ganado». Borras se consideraba a las corderas jóvenes - de entre uno y dos años-que aún no habían parido, y a las ovejas vacías, que tampoco lo habían hecho. Les exigían, pues, que les pagasen ciertos animales -carneros y borras- en función del número de cabezas que Ilevaran a pastar por esos territorios. Estos tributos los cobraban los señores a los rebaños trashumantes como un impuesto de paso por permitirles utilizar los caminos de sus dominios -el pasaje- y transitar por las inmediaciones de sus fortificaciones -la castellería-, para contribuir a la reparación, mantenimiento y vigilancia de las mismas ${ }^{16}$. Alegan los representantes de ambos concejos que no tienen derecho a cobrárselos porque ellos lo tienen así acordado en yunta y, por lo tanto, reconocido por sus respectivos señores $^{17}$, que les tienen jurado guardar sus usos y costumbres; y por la monarquía castellana, que se lo tenía reconocido y asegurado a los concejos. Ante ellos podrán querella, si fuera necesario, de que sus alcaides les quebrantan sus

14. «e tiraron la dicha duda e declararon que pudíen entrar de día e con sol los ganados de los dichos lugares de Ençiso e de Muro a los dichos términos de Ençiso e de Muro, e a qualquier dellos, por los dichos términos acomarcantes de Préxano e de San Pero e de Vea, e paçer las yervas e bever las aguas de día e con sol, sin coto e sin caloña alguna, non faziendo daño en los panes e viñas, ni en las cosas por las dichas ordenanças acotadas e que sopieran verdad que siempre lo usaran assí los dichos conçejos de Ençiso e de Muro» (Doc. 1).

15. $C D H, 122$.

16. GARCía DE VALDEAVELLANO, L. Curso de historia de las instituciones españolas. De los orígenes al final de la Edad Media, págs. 606 y 252, respectivamente.

17. «por razón que los dichos conçejos avían pasto en los dichos términos, unos con otros con sus ganados de día e con sol, e lo ovieran ansí suelto sin coto e sin calonia en todo tiempo, según que lo avían firmado por sus cartas de abenençias e ordenanças que sobrello tenían, e que los dichos alcaydes pedían e pidieron el dicho castellaje sin derecho» (Doc. 4). 
abenençias. Se trata, pues, de un abuso que cometen éstos y, parece, que sin el consentimiento de sus señores ${ }^{18}$.

El 27 de septiembre de 1422, ambos concejos revalidan los anteriores acuerdos. La Dehesa de los Huertos de la aldea de Muro de Entrambasaguas continúa vedada a los ganados de los vecinos de Enciso, bajo las penas y multas acostumbradas $^{19}$. Otro espacio vedado para los ganados de los vecinos de Enciso son las dehesas de las Sernas y los Villares, situadas en el término jurisdiccional de Muro de Aguas. Desde sus mojones hacia el caserío de la villa y hasta el Arroyo de Vallaroso, desde que sale de la Dehesa de los Huertos de la aldea de Muro de Ambasaguas. No obstante, ese arroyo tendrá un aprovechamiento comunero y les servirá de abrevadero, pues los bebederos de arroyos y fuentes solían aprovecharse siempre asín ${ }^{20}$; tampoco podrán aprovechar la montanera de robles -landes- y encinas, ni coger las bellotas, y el vecino de Enciso que fuera sorprendido cogiéndolas, pagaría de multa dos maravedís y perdería las que tuviera cogidas y el costal -saco grande y de tejido basto- en que las llevase. De noche o de día. Esto nos indica que aún no habían transformado todo el terreno baldío de los Villares y las Sernas en terreno de uso agrícola permanente. Pero el proceso de roturación de esos terrenos continuaba, y en él participaban también vecinos de los concejos limítrofes, como lo atestigua la toponimia menor que delimita estos pagos: rozas, piezas... ${ }^{21}$. El terreno sembrado se protegía siempre de las intromisiones del ganado y cualquier vecino podía denunciar el daño en cualquier pieza, aunque no pillase in fraganti al ganado que hacía el daño ${ }^{22}$.

18. La percepción de estos tributos de manera abusiva era habitual en la Corona de Castilla en la Baja Edad Media. ARGENTE DEL CASTILLO OCAÑA, C. La ganadería medieval andaluza. Siglos XIII-XVI (reinos de Jaén y Córdoba), II; 641-642 (castillería), 643-645 (borra).

19. La cabaña de ovejas y de cabras pagará un carnero cada vez que entre; menos de treinta cabezas, cada una, pagará un cornado; los bueyes, vacas, yeguas, rocines -caballos de mala traza, utilizados para labores de acarreo, arrastre y tiro-, asnos, asnas y mulos, cada cabeza un maravedí. Las crías de todos estos ganados, mientras que mamasen, no pagarán multa; la manada de puercos -más de 25 cabezas- 12 maravedís, menos de 25 cabezas, cada una, media blanca. Y no podrán huir una vez que el dehesero los haya sorprendido dentro de la dehesa.

20. En 1448, el Bebedero del Sotillo, en Torremuña, «que solía ser cunbrero para bever e pasçer con sus ganados e amajadar amos los dichos conçejos» se declara también de aprovechamiento comunero para los ganados de los vecinos de Hornillos de Cameros y de Torremuña, no comunal sólo para los de Torremuña, porque su señora, que actúa como alcaldesa de arbitradora de avenencia lo considera «mucho más provechoso e conviniente para amos los dichos concejos»; y ambos concejos -a los que consulta la abadesa sobre ello-, están de acuerdo con su decisión $(C D H, 124)$.

21. El mojón del pago va «... por el poyo de las pieças... e salle por medio de la pieça que es agora de Fernán Garrido, de Préxano... derecho al somo de la pieça de los Villares, que es de Rui Díaz, que fue de Pero Fernández de Ocón, vezino de Ençiso... al cabeço de somo de la Solana, que dizen de la Roça» (Doc. 5).

22. Si un vecino de cualquiera de los dos concejos encontraba una pieza suya sembrada dañada, y tenía sospecha de que habían sido ganados de los vecinos del otro concejo los que 
Sobre los deheseros encargados de hacer cumplir estos acuerdos, indican que serán ocho, puestos en enero y de común acuerdo por ambos concejos, y que han de ser hombres de buena fama y sin sospecha. Cuando pongan una multa al ganado que sorprendan en estas dehesas y ordenen al pastor que lo saque de ellas, si éste no quiere hacerlo, podrán imponerle la misma multa y pena otra vez; podrán multar a cualquiera que no respete estos acuerdos y, si alguien a quien han multado, no quiere pagar la multa que le han impuesto, tendrá que pagar el doble. El carnero que tomen en prenda a la cabaña que sancionen no podrá ser manso, morueco, castrón ni çencerrado. Si lo es, perderán el derecho que tenían a imponer la multa. El manso es el carnero capado que se usa como guía del rebaño y solía llevar al cuello un gran cencerro denominado truca. Cuando necesita mover el rebaño, el pastor lo lleva a su lado y el resto del rebaño le sigue; el morueco es el carnero reproductor, el que es seleccionado para semental; el castrón es el carnero capado. Se les capaba por su piel y porque su carne era muy apreciada, aunque su lana pesaba menos que la de los enteros -carneros sin capar-; y los carneros çencerrados son los que guían al rebaño con sus cencerros. El cencerro formaba parte del patrimonio familiar y servía para que el rebaño marchase y comiese reunido y para que el pastor lo tuviera localizado en todo momento, porque el sonido de cada uno era diferente al de los otros rebaños. Por eso se prohibía a los deheseros tomar en prenda un carnero çencerrado, para evitar que el ganado quedase radío, es decir, que el rebaño se dispersase y se perdieran las reses.

Declaran asimismo que con esta «ordenança de hermandad e composición» no derogan, ni en todo ni en parte, los acuerdos vigentes entre ellos hasta entonces -los del 29 de septiembre de 1373, que incluirían la aclaración de la junta del 8 de abril de 1392 comentada-; y, como ocurre en estos casos, incluyen una cláusula en que ambos concejos se ofrecen garantías de que respetarán lo acordado bajo pena de fuertes multas.

También estaban obligados a respetárselos sus respectivos señores feudales, pues la monarquía castellana les reconocía y garantizaba ese derecho a los concejos del reino ${ }^{23}$. Por ello, el 25 de octubre de 1422, Diego Pérez Sarmiento, señor de la villa de Enciso, y Juan Ramírez de Arellano II, Señor de los Came-

le habían causado el daño, podía denunciar a los que él creyera que le habían causado el daño ante los alcaldes del concejo del que eran vecinos; y éstos debían exigirles a los denunciados que demostrasen que no lo habían hecho, o pagasen el daño. La denuncia sobre esta sospecha tendrá que hacerla el afectado antes de nueve días desde que le ocasionaron el daño; si no lo hacía así, se entendía que renunciaba a su derecho.

23. Alfonso X el Sabio a Velilla de Ocón, en 1257; la abadesa de Santa María de Herce al concejo de esta villa, en 1263, los acuerdos que había suscrito con el concejo de Arnedo; Sancho IV, Fernando IV y Alfonso XI de Castilla, a los concejos de Munilla, Arnedillo, Robres del Castillo, Ocón, La Santa, Hornillos de Cameros, Torremuña, Yanguas, Enciso y Préjano, que se habían quejado ante ellos de que sus respectivos señores feudales ni les reconocían ni les respetaban los usos y las costumbres que tenían. HERCE, págs. 422-423 y 456. 
ros y de la villa de Muro de Aguas, se comprometían públicamente -y por escrito- a respetárselos a sus vasallos ${ }^{24}$.

El 11 de julio de 1490, ambos concejos celebraban yunta en Totico y revalidaban los acuerdos alcanzados en las yuntas de 1373; y como los documentos que recogían el texto de esos acuerdos estaban en mal estado de conservación, pedían que se hiciera un traslado notarialmente compulsado de los mismos. El dato es interesante porque evidencia que estos acuerdos estuvieron vigentes durante toda la Baja Edad Media ${ }^{25}$.

\subsection{Con el concejo de San Pedro Manrique}

Alcanzan los representantes de ambos concejos diversos acuerdos en las yuntas que, el 27 de enero de 1383, celebran en el lugar acostumbrado, la Varguilla de Entrambasaguas, para regular el aprovechamiento económico de sus comuneros. En primer lugar, establecen una mancomunidad de pasto en la que sus ganados tendrán pasto común de día, respetando los pagos - de cereal y viñas- y las dehesas acostumbradas. Cada cabaña de ganado menudo que pase la noche en el término del otro concejo pagará de pena una res; bueyes y yeguas, cada cabeza, un dinero de multa. En las dehesas acotadas, la pena doblada; y el daño hagan deberán pagarlo, pudiendo elegir la persona que ha sufrido el daño si cobra el daño o la multa que les impongan. En los pagos cerealistas están vedadas las hojas sembradas desde que se siembran hasta que se recoge en ellas la cosecha, y los rastrojos del 1 de marzo al 15 de agosto -como en el caso anteriormente comentado-.

Con respecto a las entradas del ganado en las dehesas de panes aclaran dos cuestiones. La primera, que el cereal que tuvieran que pagar los propietarios del ganado que hubiera dañado el sembrado deberán entregarlo el día de San Gil, el primero de septiembre, es decir, nada más terminar de acarrear la cosecha. La segunda, que si no se han segado las mieses ni se han retirado los haces de mies de los rastrojos para el día de la Virgen de Agosto deben comunicárselo ambos concejos, el uno al otro, para prohibir la entrada al ganado hasta que sus vecinos los acarreen. Fijar una fecha fija para retirar las cargas de mies de los sembrados no era tarea fácil y, en la Baja Edad Media, son muy abundantes en la región los conflictos por este motivo ${ }^{26}$.

24. Docs. 6 y 7.

25. «e porque avían voluntad que las dichas ordenanças fuesen firmes para siempre e las buenas amiganças no se perdiesen, e no aviendo voluntad de las desatar ni quebrantar, en todo ni en parte por alguna manera ni razón, mas aviéndolas por estables e por firmes en la manera que fueron fechas ante al tiempo que las ordenaron, e por que no se moliesen ni perdiesen por delongança de tiempo» (Doc. 10).

26. Así están documentados en Anguiano (1376 y 1436), Santo Domingo de la Calzada y Villarejo (1490), Bañares (1460), Hornillos de Cameros y Torremuña (1448), etc. HERCE, págs. 487-490. 
En segundo lugar, el concejo de Muro de Aguas logra un acuerdo de buena vecindad con el de Vea, por el que cualquier vecino de un concejo que fuese a vivir al otro puede pasar con sus añales, es decir, con sus ganados y con la crías del año que éstos tuvieran, sin pagar tributo ese año por un añal al concejo donde se ha trasladado a vivir. Parece que esta medida se refiere sólo a los añales de los ganados domados, es decir, estantes, de labor -yuntas de bueyes para la labranza- y de carga y tiro - de los que se mencionaban rocines, mulos y asnos-, con los que podrán pastar de día y de noche -pacer y yacer- en los términos donde lo hagan los otros ganados de labor de los vecinos de ese concejo. Esta medida ayudaría a los campesinos -sobre todo, a los más pobres, a los que sólo poseyeran un añal- a sustituir la fuerza de trabajo animal cuando los animales que tuviesen murieran o fueran tan viejos que no pudieran aprovecharlos ya en el laboreo agrícola.

También regulan el aprovechamiento forestal en sus términos y no permiten a sus vecinos disponer libremente de estos recursos. Para poder cortar leña y ramón en ellos sus vecinos deberán pagar unas tasas proporcionales a la cantidad de madera o de ramón que corten. Con esta medida los concejos obtienen recursos económicos y evitan -al menos, lo intentan- la sobreexplotación de sus bosques, retrasando su degradación y su total desaparición. Así, quienes corten «pied de robre o de carrasco que se pueda quadrear para madera de casa o para pied», por cada pie, pagarán cuatro maravedís; de los otros árboles -más pequeños, de otro tipo-, por cada pie, dos dineros y medio ${ }^{27}$. Del corte de ramas para que las coma el ganado - de la matança-, cada cabaña -más de treinta cabezas- de ganado menudo, pagará un carnero, o tres maravedís; por menos de treinta cabezas, por cada res dos dineros; cada res de ganado mayor, dos dineros; por la carga de ramón pagará un maravedí, el haz -es decir, la gavilla de ramas- cinco dineros, el palanco -la estaca inflexible, el garrote fuerte o magazo, como se le dice en Muro de Aguas en la actualidad-sólo tres. Es posible que, como en el caso de los acuerdos anteriormente analizados de Muro de Aguas con Enciso, esta medida afectase sólo a los terrenos comuneros entre ambos; pero nada indica el texto del documento al respecto. Aún así, sería más restrictiva que en ese caso, pues el vecino de cada concejo también pagaría esa tasa por aprovisionarse de leña verde, madera y ramón, en el término jurisdiccional de su concejo. En el caso anterior, sólo en el comunero situado en el término del otro concejo ${ }^{28}$.

En las ordenanzas de la Villa y Tierra de Yanguas, aprobadas en 1460, se advertía a los que una vez segada la hoja sembrada dejaban haces de mies en ella más allá de esa fecha, para multar a los ganados que entrasen, que debían dejar una entrada libre para que pudieran entrar rebaños a pastar el rastrojo, respetando los haces de mies. DELGADO MARTíNEZ, C. Apuntes sobre la vida rural de la Villa y Tierra de Yanguas (Soria). Siglos XII-XVI, pág. 157.

27. Doc. 2.

28. En la sentencia arbitral entre los concejos de Munilla y Torremuña del año 1449, se prohibía el ramoneo y se castigaba con penas mayores: «Otrosí mandaron que ningún vecino ni 
Por último, como siempre, las partes se ofrecen garantías mutuas para cobrar las penas -en especie- y las multas -en dinero- que los deheseros impongan a quienes no respeten esta normativa.

\subsection{Con el concejo de Préjano}

Ambos concejos enviaban periódicamente a sus representantes a celebrar juntas al Ocijo, «en el logar do se parten los términos de nos, los dichos conçejos», y, en la que celebraron el 16 de junio de 1390, éstos alcanzaron diversos acuerdos sobre el aprovechamiento de sus comuneros, amojonándolos, y revalidando también una mancomunidad de pasto - de las que se denominan soles- y de monte, mediante las que regulaban meticulosamente el pastoreo, la corta y la montanera, para evitar el agotamiento de los recursos ganaderos y forestales de los mismos.

En cuanto al pastoreo, el vecino de Muro de Aguas que apacentaba su rebaño en los comunales de su término concejil podía llevarlo, de día, a los comuneros situados en el término concejil de Préjano sin pagar impuesto de aprovechamiento de hierbas, y debía regresar al suyo antes de caer la noche; y viceversa. Sin embargo, por ramonear y cortar en ese mismo comunero sí debía pagar un impuesto de aprovechamiento de leñas. Las tasas que debían satisfacer, en función del tipo de madera que cortase y de la cantidad de ramón que cogiera, eran similares a las acordadas en la yunta de 1373 entre Muro de Aguas y Enciso, ya analizadas ${ }^{29}$. Esta medida, como en el caso anteriormente comentado, suponía una importante fuente de ingresos para ambos concejos y trataba de evitar la desaparición de sus bosques. La montanera la desvedan desde el Veranillo de San Martín -el 11 de noviembre-, para no agotarla antes del invierno, y protegen el espacio destinado a un uso agrícola permanentemente de las intromisiones del ganado, tanto los pagos de huerta como los de viñas y cereal; tal como se vedaban en toda la región y como establecían ya en los acuerdos

alguno de los dichos logares e sus aldeas que no puedan faser matanza alguna, ni ninguno que sea, para ganado maior ni menor; e si la fisiere e fuere para ganado mayor que aya de pena cinquenta maravedís, e si fuere para ganado menudo que haia carnero; salbo que pueda cortar fasta cinco ramas; e, éstas, que sean pequeñas; e, si fuesen grandes, que pague la dicha pena; e si cortare más ramas, et si tirare la prenda, que haya la pena doblada e lo enttregue el dicho alcalde, segúnd que dicho es» $(C D H, 125)$.

29. Por una carga de leña verde un maravedí, por una carga de ramón ocho dineros, por un haz de ramón cuatro dineros, por una estaca -un palanco- dos, por un pie de árbol dos maravedís. En cuanto a la madera que necesitasen para construir y reparar sus viviendas, para fabricar sus herramientas de trabajo y recipientes para almacenar sus provisiones, podrán cogerla gratuita y libremente en sus comuneros, especificándose en la yunta de 1450 que: «toda fusta que fuere menester para aradro, o a hazer casa, e para çellos de cubas e tinos y para las heras, que sea franco todo tajo para todos sin coto e sin caloña de los unos a los otros en los dichos términos» (Doc. 8). 
entre Muro de Aguas y Enciso antes comentados: la hoja sembrada desde que se siembra hasta que se retira de ella la cosecha, y la que está en barbecho desde el 1 de marzo hasta la Virgen de Agosto; y las penas y multas impuestas a quienes incumplan esta normativa también son las mismas ${ }^{30}$.

En segundo lugar, establecen entre ambos concejos una hermandad -un pacto, una alianza, un convenio-, de ayuda mutua, que es una traducción bajomedieval del apellido, de la que se precisan dos cuestiones. La primera, que los vecinos de Muro de Aguas pueden comprar y vender cuantas provisiones necesiten «en Préxano e en su término, e sacarlas e levarlas, asý pan e vino, e carne muerta e biva, e todas las otras cosas que se pueden conprar e bender». En la yunta de 1450 se precisa más y se indica que al mismo precio, "tanto por tanto», que sus vecinos. Y viceversa. La segunda, que si el concejo de Muro de Aguas necesitase «acorro»-auxilio- «de conpañas» del concejo de Préjano, éste deberá ayudarle con «la más conpaña que pudiermos, do fuéremos llamados de vos, el dicho conçejo». En la yunta de 1450, precisan que el concejo de Muro de Aguas auxiliará al de Préjano con una conpaña de 25 hombres para y donde se le requiriesen; y si el concejo de Préjano tuviese necesidad de ayuda del de Muro de Aguas, éste deberá auxiliarle con una conpaña de 15 hombres para y donde se le requiriesen también. Y el concejo que pedía la ayuda debía pagar "la costa», es decir, el mantenimiento de los hombres con los que le auxiliaba el otro ${ }^{31}$.

Restringen asimismo el aprovechamiento ganadero de sus comunales y comuneros a los ganados de los vecinos de ambos concejos. Sólo podrá pastorear sus rebaños «en los términos de nos, los dichos conçejos» quien resida «afirmando casa continuadamente en qualquier de los dichos logares Muro e Entranbasaguas e Préxano, do recibiere la dicha vecindad», prohibiendo a sus vecinos traer ganado ajeno junto al suyo a pastar en ellos de día y de noche, «por pastos nin por yazijas».

Esta medida, a mi entender, trataba de impedir que los vecinos ricos de las ciudades y villas más importantes del entorno, como Arnedo, Alfaro, Ágreda, Yanguas, Cervera del Río Alhama, Logroño, Calahorra, Soria, etc..., en las que residían, adquiriesen mediante compra la carta de vecindad en cualquiera de los dos concejos y, ejerciendo los derechos que el estatuto jurídico de vecino importaba, pudieran comprar las mejores tierras - pues poseían el dinero con que

30. En la yunta de 1450 se explicitan todas las penas y multas que se impondrán a los ganados que no respetasen el pago de cereal cuando estuviera acotado. En el texto del documento que recoge los acuerdos de la yunta de 1390 -doc. 3-, al estar el soporte del mismo, el pergamino, en pésimo estado de conservación, esta parte de los acuerdos casi no se puede leer, no obstante, parece que recoge la misma casuística, penas y multas, que las de la yunta de 1450 -doc. 8-.

31. Docs. 3 y 8, respectivamente. 
hacerlo- para destinarlas a la producción de cereales panificables, vino, aceite y plantas textiles; Ilevar sus rebaños a pastar al comunal del término del concejo en el que la hubieran comprado y a los comuneros que éste tuviera acordados con los limítrofes, beneficiándose de sus pastizales en perjuicio de los vecinos de estos concejos que sí residían en ellos, para obtener carne, lana, cuero y piel, queso, mantequilla, etc..., para el abastecimiento de las carnicerías y los talleres artesanales de esas y otras ciudades, quizás, para instalar ellos mismos esos talleres o molinos en esas villas; las forestales a proporcionar madera, etc..., para la ampliación de estos núcleos urbanos, etc. Ellos no iban a trabajar esas tierras, ni a pastorear esos rebaños, ni a cultivar -valga la expresión- esos bosques, porque ni siquiera residían en Muro de Aguas o en Préjano, sino que cedían su explotación a renta o la Ilevaban a cabo mediante jornaleros. Esta estrategia de las élites económicas de la región está bien documentada en el siglo XV en el Valle del Cidacos y el Camero Viejo. Miembros destacados de linajes como los Vera, Sánchez de Alfaro, Angulo, Librán, León, Barrionuevo, Vidaurreta, Díaz de Fuenmayor, Jiménez de Enciso, etc..., que mantenían en buena medida -muchos de ellos- una relación feudovasallática directa con los Ramírez de Arellano, señores de Muro de Aguas, desde las villas y ciudades más importantes arriba citadas, en las que residían, orientaban las actividades económicas de los campesinos de las villas y aldeas más pequeñas que buscaban la subsistencia, el autoabastecimiento, hacia la producción de los artículos antedichos, que eran muy demandados en esas ciudades por una población en continuo aumento después de las crisis de mediados del siglo XIV ${ }^{32}$.

Por último, como en casos semejantes, otorgan autoridad pública a los guardas que velarán por el cumplimiento de esos acuerdos, los jurados yunteros, que serán elegidos en las yuntas, se les tomará juramento en cada concejo y, usando de su oficio, serán creídos por su palabra, confirmando la jura que hicieron. En segundo lugar, se ofrecen garantías de que cumplirán lo pactado bajo pena de fuertes multas. Indican, además, que si hubiera que aclarar o solucionar cualquier disputa entre partes relativa a lo acordado en las yuntas, que se reúna la yunta cuando sea necesario y, si cualquiera de las partes no quiere asistir, que pierda su derecho y pague a la otra, a la que sí cumple con la obligación que tiene de asistir, las penas que se le impongan en dicha yunta.

El 29 de septiembre de 1450, reunidos en yunta en el Ocijo, sus representantes revalidan los acuerdos anteriormente logrados y precisan algunas cuestiones relativas a los mismos que, en parte, ya hemos analizado, como las que atañían a la hermandad que existía entre ellos; en cuanto a la buena vecindad que se buscaba entre los habitantes de ambos concejos, que el que tenga propiedades en los dos términos que pague los tributos en los dos por las propiedades que

32. HERCE, 403-411. 
tuviere, salvo si se va a vivir al otro concejo. También, que si algún vecino de Muro de Aguas y de Enciso sospechase que personas extrañas que están en sus términos dañan, roban y hacen mal, que los denuncie a los oficiales de sus concejos y que estos los apresen hasta que aclaren si son culpables o inocentes; y, tanto si son hallados culpables como si son hallados inocentes, que sean ejecutados o puestos en libertad por ambos concejos de común acuerdo. La villa es un marco de convivencia perfectamente definido y quienes no están encuadrados social, fiscal, política y religiosamente en la misma, son vistos con «resapio» y se les considera sospechosos de quebrantar el orden establecido.

En cuanto al ramoneo, sí permiten a los vecinos de un concejo ramonear en el comunero que su concejo tiene en el término del otro sin pagar tasa alguna, sin cortar el árbol por el pie, sin cortarle los cornales, y sin trasmocharlo del todo, dejándole siempre podadizo, es decir, una rama viva y joven para que se haga rama madre y pueda coger altura sin perder enteramente la copa y frenar el posible envejecimiento del árbol. A la vez que, cortándole las ramas pequeñas que se brotan en gran número de los cornales -las çimas-, éstos adquieren más vitalidad, grosor y tamaño ${ }^{33}$. Si lo hacen, deberán pagar 4 maravedís por el pie y 2 por el cornal, sin dejar podadizo. Esta normativa iría destinada a garantizar la subsistencia de los rebaños de ovejas, de cabras, y de ganados de labor de aquellos vecinos que no pudieran pagar el impuesto de leñas y supondría una fuerte presión sobre el bosque, acelerando su degradación y tensando el equilibrio entre el espacio de uso agrícola y el de uso forestal, y el aprovechamiento ganadero de ambos, porque, es obvio, que hubo de perjudicar mucho a la montanera, y a los cerdos había que alimentarlos como fuera porque eran básicos para garantizar la supervivencia de la población en el invierno.

Revalidan la mancomunidad de pasto vigente - de día-, que regula el pastoreo estante entre ambos concejos y respeta los pagos de huerta, cereal y viña, y las dehesas acostumbradas, explicitando las penas y multas que se impondrán a los ganados que entren en los pagos de cereal cuando están acotados, y a los que majadeen en el comunero del otro concejo ${ }^{34}$. En cuanto a la dehesa que

33. «Otrosí hordenamos nos, los dichos conçejos, que los vezinos de la villa de Muro y de Entramasaguas que puedan cortar leña y ramón y leña verde y seca del término de Préxano sin coto e sin caloña, e que puedan hazer matança de ramón y de caxigo y de revollo, no cortando por el pied ni por cornal, salbo por las çimas; e que dexe podadizo en la dicha matança» (Doc. 8).

34. La cabaña de ganado menudo del vecino de Muro de Aguas -más de treinta cabezasque pasase la noche -que yoguiese o yaziese- en el término de Préjano, o se apacentase en dicho término después del sol entrado -de que anochezca-, o antes de que salga -de que amanezca-, pagará de pena un carnero y de multa ocho maravedís; y si el pastor pagase al jurado yuntero diez maravedís que éste no le tome en prenda el carnero. Si el pastor no le quisiere entregar el carnero, que el jurado vaya a Préjano y que su alcalde le pague el doble; y si el alcalde de Préjano no se lo quisiere pagar, que se lo pueda cobrar en bienes del concejo. Si el pastor no le entrega prenda, que el jurado le tome el carnero y lo guarde tres días y, si en esos tres días, el 
pueden utilizar en exclusiva los vecinos de uno de los concejos, es considerada espacio vedado también para los ganados de los vecinos del otro, y si alguno de éstos labra en ese término concejil y sus ganados entran en dicha dehesa, deberá pagar la misma multa que los vecinos de ese concejo. Normalmente, en la región, en el Camero Viejo en concreto, se permitía a estos ganados domados empleados en el laboreo agrícola, bueyes y vacas principalmente, regresar a su término concejil con la noche ya cerrada y no al anochecer como el resto de los ganados, o pasar la noche en el término del otro concejo, para descansar y aprovechar mejor la siguiente jornada de trabajo, pero debían Ilevar el alimento cada uno en su talega ${ }^{35}$.

También se prohíbe -y se castiga duramente- que los ganados traspasen los comuneros: si los ganados mayores de los vecinos de un concejo entran en términos del otro concejo que no son comuneros con el suyo cada res deberá pagar cinco dineros de multa, si la cabaña de ganado menor entra «adelante de como está tasado por do pueden paçer los dichos conçejos», que el jurado yuntero le pueda tomar al pastor «carnero sin pena e lo pueda matar».

Revalidan asimismo la prohibición de que sus vecinos Ileven ganado ajeno a pastar con el suyo a sus comuneros, salvo en el caso de que alguno de ellos tuviese contratado a sueldo a un pastor de otro concejo, en este caso, éste podrá llevar a apacentar a los comuneros de ambos términos con el rebaño del vecino de estos concejos que le ha contratado un pequeño hato -que no llegue a cabaña, es decir, de hasta treinta cabezas-de excusa, es decir, sin tener que pagar arbitrio de herbaje, ni pena, ni multa alguna por ellas ${ }^{36}$. Si los deheseros sospechasen que en las cabañas de los vecinos de ambos concejos hay algún ganado ajeno, que tomen jura al pastor ante el alcalde del concejo en que estuviera; si no quisiere jurar el pastor, que pierda el carnero y que los deheseros lo guarden hasta nueve días; y, si en esos nueve días, no quisiere jurar el pastor, que pierda el carnero o los carneros que le tomaron en prenda. Ningún vecino de estos concejos podrá tener ganado ajeno con el suyo en los comuneros de estos concejos, salvo del que fuera morador y tuviera casa en el concejo en el que tiene carta de vecindad. Cuando estos recursos -el arbolado, el pasto y la

que ha cometido la infracción no paga la prenda y la multa, que el jurado pueda aprovecharse del carnero que le ha tomado en prenda.

35. «E más mandamos que los bueyes domados no ayan pena fasta la noche a la estrella salida; y esto se entiende fuera del pago o de las deesas» (Acuerdos alcanzados por los concejos de Robres del Castillo y La Santa en la yunta del año 1495. CDH, 284); «e de diez ayuso que pueda yacer trayendo cada uno su talega de fuera de los vedados» (Sentencia arbitral pronunciada el 8 de febrero de 1412 entre los concejos de La Santa y Munilla. $C D H, 86)$.

36. «salvo si, por aventura, algún vezino de nos, los dichos conçejos, tobiere moço a soldada, que pueda traer el moço con las de su amo fasta treynta reses; y éstas que no sean carnereadas de día ni de noche mas que las de su amo» (Doc. 8). 
Impuesto de aprovechamiento de leñas en las yuntas de Muro de Aguas. Tasas

\begin{tabular}{|c|c|c|c|c|}
\hline & Con Enciso (1373) & $\begin{array}{c}\text { Con San Pedro } \\
\text { Manrique (1383) }\end{array}$ & $\begin{array}{c}\text { Con Préjano } \\
(1390)\end{array}$ & $\begin{array}{c}\text { Con Préjano } \\
(1450)\end{array}$ \\
\hline \multicolumn{5}{|l|}{ Leña verde } \\
\hline Carga & 1 maravedí & & 1 maravedí & \\
\hline Cortar pie de árbol & 4 maravedís & 4 maravedís & 2 maravedís & 4 maravedís \\
\hline Cortar cornal & 1 maravedís & & & $\begin{array}{c}2 \text { mrs. (sin dejar } \\
\text { podadizo) }\end{array}$ \\
\hline \multicolumn{5}{|l|}{ Ramón } \\
\hline Carga15 dineros & 1 maravedí & 8 dineros & & libre \\
\hline Haz o gavilla & 5 dineros & 5 dineros & 4 dineros & libre \\
\hline Palanco 3 dineros & 3 dineros & 2 dineros & & libre \\
\hline \multicolumn{5}{|l|}{ Matanza de ramón } \\
\hline Ganado mayor. Cabeza. & 2 dineros & & 2 dineros & \\
\hline Ganado menor. Cabaña. & 8 maravedís & & 1 carnero & \\
\hline $\begin{array}{l}\text { Ganado menor. } \\
\text { Menos de } 30 \text { cabezas }\end{array}$ & 2 meajas (res) & & 2 meajas (res) & \\
\hline $\begin{array}{l}\text { Madera para } \\
\text { herramientas }\end{array}$ & libre & libre & libre & libre \\
\hline
\end{tabular}

montanera- escaseaban ya sus términos -y esta medida sería una evidencia de ello- los concejos restringían su aprovechamiento a sus vecinos, como ocurría en el Valle del Cidacos y en el Camero Viejo por estas fechas ${ }^{37}$.

Los terrenos que los vecinos de cada concejo siembren en sus comuneros deberán respetarse y se considerarán ese año pagos de cereal; y se guardarán en «las dehesas que fueran echadas», la hoja sembrada desde que se siembra, y la que está en barbecho del primero de marzo a Santa María de agosto. Esto nos indicaría que todos estos pagos no sembraban todos los años, sino que a algunos, a los que no se echaban ese año, se les alargaba el barbecho -sistema de eriazo- para que recuperasen antes su fertilidad, en función de la calidad del terreno, de las necesidades de alimentos de los vecinos, de sus posibilidades técnicas para llevar a cabo su cultivo, etc ${ }^{38}$. Sin duda, el crecimiento demográ-

37. En 1430, los concejos de Arnedo y Herce prohíben a sus vecinos traer ganado foráneo a pastar a sus comuneros $(C D H, 112)$. También restringían los concejos el aprovechamiento forestal de su término a sus vecinos cuando era necesario y, por este motivo, en 1423, los concejos de Munilla y de Hornillos de Cameros, les prohíben a sus vecinos cortar hayas en el Hayedo de Santiago con vecinos de Torremuña y de otros lugares $(\mathrm{CDH}, 107)$.

38. En 1712, el concejo de Muro de Aguas debía indicar a sus vecinos y a los del concejo de Préjano -y viceversa-, con el que tenía suscritos acuerdos sobre el aprovechamiento de sus comuneros, cuáles iban a ser los terrenos que iban a sembrar de cereal en su término concejil en el mes de octubre, cuando comienza la siembra, ya que el inicio de la siembra, de la siega 
fico del siglo XV obligó a los campesinos a roturarlos y construir en ellos los pagos cerealistas a los que alude el documento para alimentar a una población en continuo ascenso. Estos terrenos cumplían en este caso, y en los otros anteriormente analizados, la función de reserva de tierra cultivable y, mientras estuvieran sembrados, el concejo los protegía de las intromisiones del ganado como a los otros, con penas y multas muy similares e imponiéndoselas con los mismos criterios que los utilizados en los acuerdos de las yuntas de años anteriores analizados ${ }^{39}$. Su situación en unos espacios tan marginales, con laderas pronunciadas, mal comunicados, sin canales de riego que garanticen las cosechas, nos hace pensar que se han construido para alcanzar el autoabastecimiento, y que en la economía de sus vecinos los intercambios son escasos. Así se explicaría que cada concejo garantice a sus vecinos que podrán comprar y vender las provisiones que necesiten en el otro concejo como si fuera en el suyo ${ }^{40}$.

El 20 de enero de 1451, Juan Ramírez de Arellano II, Señor de los Cameros y de Muro de Aguas, confirma estos acuerdos a sus vasallos de dicha villa, a condición de que Diego González de Toledo, Señor de Préjano, se los apruebe a los suyos.

Estos acuerdos analizados nos indican que, en las décadas finales del siglo XIV, los habitantes de la sierra riojabajeña, en buena medida, habían transformado el bosque de sus términos concejiles en un cultivo -valga la expresión- de las especies arbóreas que les ofrecían más rentabilidad, y que explotaban, por una parte, para satisfacer la demanda cada vez mayor de madera para la construcción, de leña para la calefacción, etc..., de una población en continuo aumento y, por otra, en función de su interés ganadero, pues necesitaban el fruto de encinas, robles y hayas -bellotas, landes, hoyes-, y el ramón, para alimen-

y de otras labores agrícolas en otros pagos -la vendimia, por ejemplo, para que las ovejas comiesen la pámpana después-, lo marcaba el concejo, para que todos los vecinos las realizasen a la vez, y cuidar así el terreno sembrado de las intromisiones del ganado mejor; $y$, después, para regular el aprovechamiento ganadero comunal del terreno de uso agrícola. Archivo Municipal de Muro de Aguas. Signat. P004/04.

39. El ganado menudo que entre en ellos tendrá de pena un celemín del cereal en el que hiciese el daño; o lo que apreciare el dueño del sembrado. El ganado mayor, cada res, tres celemines del cereal en el que hiciese el daño; o lo que apreciare el dueño del sembrado. Las penas y multas que se impondrán a estos ganados, hasta el primero de marzo, serán de la mitad y, hasta esa fecha, que la cría que mamase, de cualquier ganado y que fuese añal -nacida ese año-, no tenga multa. El que no quiera pagar la pena y la multa impuestas por los jurados pagará el doble; y que los oficiales concejiles de donde fuere vecino el rebelde sean obligados a pagárselo a estos jurados.

40. También en los acuerdos con Enciso, en 1373 y 1422 (docs. 1 y 5), y con Préjano, en 1390 (doc. 3). 
tar su cabaña estante. Las instituciones encargadas de protegerlo eran los concejos, mediante la regulación del pastoreo, el corte y la montanera en sus términos jurisdiccionales, imponiendo diversas tasas a los vecinos de las villas por llevar a cabo esas prácticas y creando reservas de pastos y arbolado en los mismos.

En cuanto al bosque en sí, los habitantes de la región favorecían la difusión de las especies de las que obtenían más rendimiento -las arriba citadas: hayas, marojos y quejigos -robles-, y encinas; lo ahuecaban para crear pagos cerealistas, que se protegían de las intromisiones del ganado como los otros que no estaban en los comuneros; y desmochaban sus árboles para aprovechar sus ramas para madera y ramón, apareciendo formaciones boscosas de porte arbustivo, carrascales y matas -los montes menores, que se mencionan ya en 1373-.

En la primera mitad del siglo XV, el crecimiento demográfico y la expansión agraria aumentaban la presión sobre el bosque en los términos de los concejos del Valle del Cidacos, de la Villa y Tierra de Soria y del Camero Viejo, y los de Muro de Aguas y Préjano, permitirán ramonear libremente -sin pagar tasas por llevar carga, haces de ramón y estacas- en sus comuneros, en los que también perdía terreno ante las roturaciones de sus vecinos que creaban en ellos pagos cerealistas ahuecándolo y roturándolo, pero también necesitaban zonas boscosas en comunales y comuneros en las que sus vecinos pudieran alimentar a sus ganados estantes y obtener leña para fabricar sus utensilios, para construcción, para calefacción, etc. Las consecuencias de una degradación excesiva del mismo serían muy negativas. Las roturaciones, a la vista de la localización de los comuneros en el mapa, habrían Ilegado al límite posible, pues en el resto de terrenos serían inabordables en la práctica y muy poco rentables debido a lo abrupto del terreno y a su altitud; y un freno también a la ganadería, que necesitaba del bosque para sobrevivir. A mi entender esto impedirá la especialización tanto de la una como de la otra. No hay más terrenos donde ampliar el terrazgo agrícola para permitir una especialización de la producción, como ocurre por esas fechas en el Valle del Cidacos -que reúne, eso sí, mejores condiciones para ello- con los cereales panificables, la vid, el olivo y las plantas textiles como el lino y el cáñamo, demandados masivamente por las ciudades del entorno, como Calahorra, Logroño o Soria, cuyos comerciantes invertían dinero en la compra y puesta en explotación de tierras que los produjeran: viñas, olivares, linares, cañamares, etc..., lo que afectaba a las economías de cientos de pequeños labradores de las villas y aldeas del entorno ${ }^{41}$. Ni tampoco podrá orientar su cabaña ganadera a satisfacer la demanda de carne, quesos, pieles, etc..., de las carnicerías de las ciudades, organizándola en rebaños homogéneos y más numerosos de ovejas, cabras, carneros, y rascos, etc...,

41. En el Cidacos Medio, para 1430, la fuerte presión demográfica había empujado a los concejos de Arnedo y Herce a convertir la mayor parte de sus comuneros en pagos de cereal y viña $(C D H, 112$; y HERCE, mapa 9, pág. 443). 
como hacen en el Camero Viejo -que contaba con buenas condiciones para ello- por estas fechas ${ }^{42}$.

Y la presión sobre los bosques continuará muy fuerte desde estas fechas en toda la región durante el siglo XVI. Los conflictos se hacen crónicos, pues una mala cosecha que reduzca significativamente el pasto de las rastrojeras, un verano excesivamente largo y seco que obligue a ramonear en exceso, el aumento de las cabezas de ganado porcino - necesarias para alimentar a una población en un crecimiento continuo-, que obligaba a sus dueños a realizar la montanera en otoño, provocarán hambres y enfrentamientos violentos entre los vecinos de estos concejos. Una prueba evidente sería el hecho mismo de que los concejos de Muro de Aguas, Enciso, San Pedro Manrique y Préjano, utilizasen estos documentos como apoyatura jurídica en pleitos que, por los mismos motivos que en la Baja Edad Media, tienen unos con otros en 1490 (docs. 1 y 4), 1522 (docs. 1, 5, 6 y 7), en 1705 (doc. 2), en 1545 y 1555 (docs. 8 y 9). En este caso, en la confirmación por el emperador Carlos I de las concordias del año 1450 entre los concejos de Préjano y Muro de Aguas, revalidando los acuerdos que habían alcanzado en esa fecha, se nos indica que ambos concejos, un siglo después, habían adelantado significativamente ya la fecha de inicio de la montanera al día de San Miguel del mes de septiembre, unos 40 días antes del Veranillo de San Martín -que era la fecha de inicio en 1390 y 1450-, y que, aún así, la necesidad empujaba a sus vecinos iniciarla antes ${ }^{43}$. En el Camero Viejo y en la Villa y Tierra de Yanguas, un siglo después, sus concejos trataban de solventar idénticos $\operatorname{conflictos}^{44}$, y en algunos se ven obligados a tomar la decisión de transformar pagos agrícolas en dehesas boyales -reservas de pastos y arbolado- para no agotar por completo sus recursos forestales. Tal sería el caso de la Dehesa del Palancar ${ }^{45}$, en Larriba, que en 1449 era una dehe-

42. En 1449, los vecinos de Munilla y Torremuña poseían pequeños rebaños homogéneos de ovejas, carneros, cabras e yrascos -machos cabríos capados- que pastoreaban por separado $(C D H, 125)$. En 1445, los vecinos de los concejos de la Villa y Tierra de Yanguas y los de San Román de Cameros, Rabanera, Ajamil y Torremuña, pastoreaban en Monte Real rebaños de ovejas y de carneros, de más de 100 cabezas cada uno; piaras, de más de 50 cerdos cada una; rebaños de vacas, de más de 20 cabezas cada uno; y de yeguas, también de más de 20 cabezas cada uno $(C D H, 122)$.

43. «[fol. 4v.] y la bíspera del dicho día de San Miguel, veynte e ocho días del mes de setienbre del dicho año, fuesen muchos vezinos de la dicha villa de Préxano, sus partes, a coger la dicha lande de grana a los dichos términos de la dicha villa de Muro y Entramasaguas, a do dizen el Palancar de la Rimada, y estando la cogiendo .... [fol. 5r.] e antes de sazonada la lande y fruto del monte se la llevar...». Archivo Municipal de Muro de Aguas. Signat. P10/02.

44. TOLEDO TOLEDO, M. Historia de la Villa y Tierra de Yanguas, págs. 216, 217, 222, 228, $229,230,231,233,234$ y 247.

45. Su nombre haría referencia a la cerca temporal de estacas o palancos con la que se rodeaba el terreno de cultivo para defenderlo, mientras estuviera sembrado, de las intromisiones del pastoreo comunal de los vecinos. 
PEDRO PÉREZ CARAZO

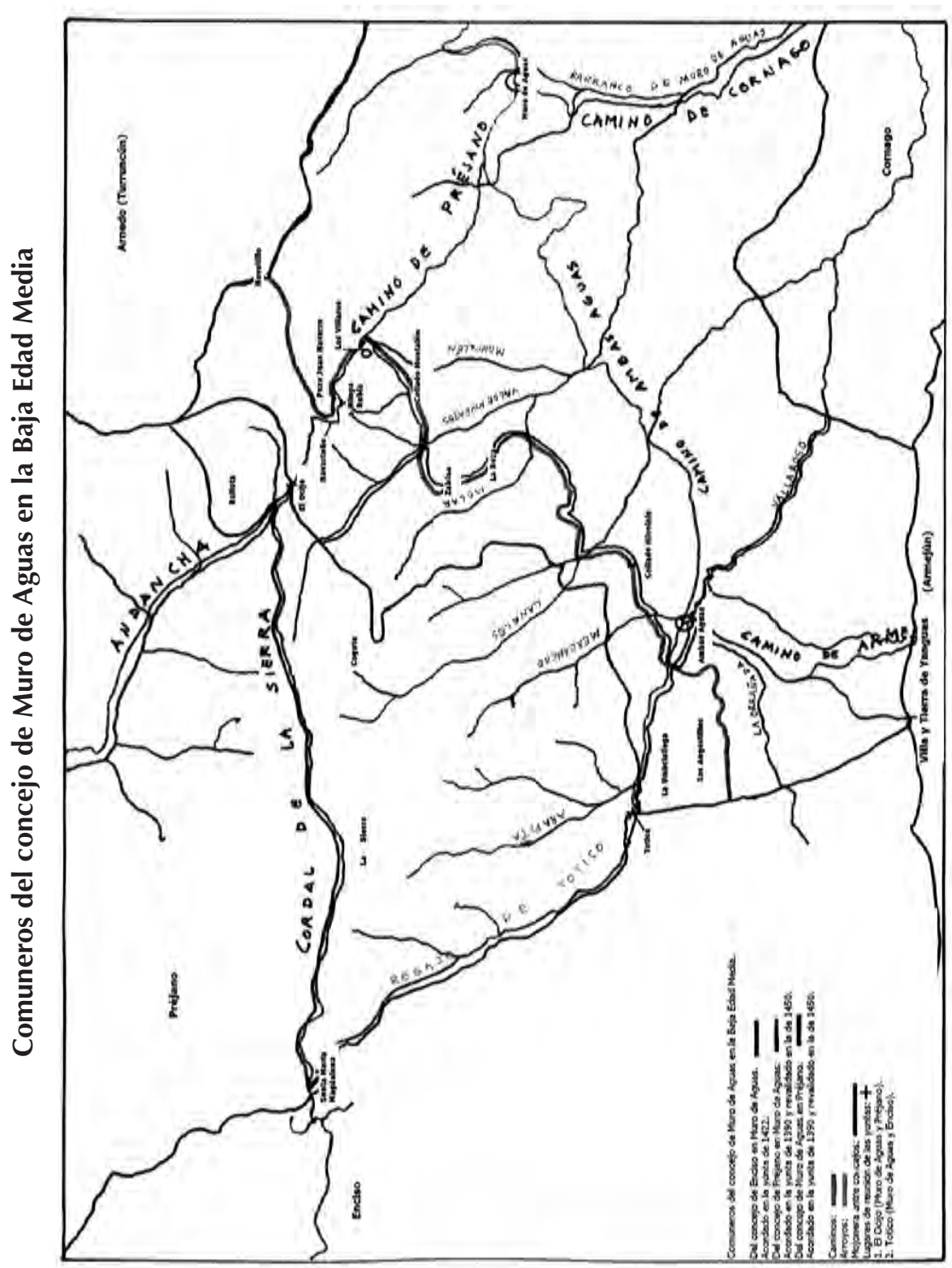


sa de año y vez que cultivaban por el sistema de eriazo, alargándole el barbecho, y que, en 1547, el concejo de Torremuña transformaba en una dehesa boyal, es decir, en un espacio comunal para mantener y guardar a los bueyes y a los otros ganados domados de los vecinos del concejo que éstos empleaban en el laboreo agrícola y en tareas de carga y de tiro, como burros, mulos y rocines, manteniéndose como tal hasta la actualidad ${ }^{46}$.

A pesar de la desarticulación del régimen comunal vigente durante el Antiguo Régimen en las décadas finales del siglo XIX, las mancomunidades de pasto y de monte acordadas en la Baja Edad Media por el concejo de Muro de Aguas con los de Enciso, Préjano y Yanguas, fueron respetadas por los vecinos de estos pueblos hasta los años 60 del siglo XX; sus representantes debidamente autorizados por las corporaciones municipales de estos ayuntamientos siguieron asistiendo a las yuntas que celebraban entre ellos; y sus vecinos respetaban escrupulosamente sus acuerdos. En estas fechas, para unos 600 habitantes, había unos treinta rebaños en el pueblo. Como en la Baja Edad Media, con pocas cabezas cada uno; los vecinos poseían abundantes burros, mulos y rocines, muy empleados en las labores agrícolas. Y practicaban un tipo de pastoreo similar. Don Francisco Cabello Cabello, natural y vecino de Muro de Aguas, que estuvo de pastor en su pueblo hasta 1960, al indicarme los términos comuneros del término de Préjano en los que podían entrar a pastar con sus rebaños, y los del término de Muro de Aguas en que podían entrar los pastores de Préjano con los suyos, me señaló los mismos parajes que en los acuerdos alcanzados por los representantes concejiles de Préjano y Muro de Aguas en las yuntas celebradas en El Ocijo en 1390 y 1450; que las multas eran superiores si se hacía el daño por la noche, y que el pastor no podía llevar su rebaño a pastar al amanecer ni al anochecer. Las mismas precisiones que hacen a los pastores en las yuntas de los años arriba citados.

\section{Bibliografía}

ARGENTE DEL CASTILLO OCAÑA, Carmen. La ganadería medieval andaluza. Siglos XIII-XVI (reinos de Jaén y Córdoba), 2 vols. Ed. Diputación Provincial de Jaén, 1991.

CLEMENTE RAMOS, Julián. La evolución del medio natural en Extremadura (c. $1142-$ c. 1525). Ed. Actas del I ${ }^{\text {er }}$ Congreso sobre ecohistoria e historia medieval; 15-56. Cáceres, 2001.

46. $C D H, 125$ (1449). En 1547 el emperador Carlos I de España, pues la monarquía posee el dominio eminente sobre todas las tierras no repartidas individualmente, autorizaba al concejo de Torremuña para hacer una dehesa boyal en el lugar de Larriba. Archivo Municipal de Ajamil de Cameros. Torremuña. Signat 068/27. 
DELGADO MARTÍNEZ, Consuelo. Apuntes sobre la vida rural de la Villa y Tierra de Yanguas (Soria). Siglos XII-XVI. Ed. CSIC, Centro de Estudios Sorianos. Soria, 1981.

DIAGO HERNANDO, Máximo. Implantación territorial del linaje Arellano en tierras Camero-riojanas a fines de la Edad Media. Ed. Rev. Berceo, 120 (1991); 65-82.

DÍEZ SANZ, Enrique. La Tierra de Soria. Un universo campesino en la CastiIla oriental del siglo XVI. Ed. Siglo XXI de España Editores, S. A.; col.: HISTORIA MODERNA. Madrid, 1995.

GARCÍA DE CORTÁZAR, José Ángel. La época medieval. Tomo II de la Historia de España dirigida por Miguel Artola. Ed. Alianza Editorial, S. A., col.: AU. Madrid, 1988.

GARCÍA FERNÁNDEZ, Jesús. Campos abiertos y campos cercados en CastiIla la Vieja. En Homenaje al Excmo. Sr. D. Armando Melón y Ruiz de Gordejuela; 117-131. Ed. Instituto de Estudios Pirenaicos. Zaragoza, 1966.

JORDANA Y MORERA, José. Algunas voces forestales y otras que guardan relación con las mismas. Ed. Imprenta de Ricardo Rojas. Madrid, 1900.

PÉREZ CARAZO, Pedro. Santa María de Herce y su abadengo en la Edad Media. Ed. IER y UR. Logroño, 2007.

PÉREZ-EMBID WAMBA, Javier. Desforestación y reforestación en Sierra Morena Occidental (siglos XIII-XVI). Ed. Actas del Ier. Congreso sobre ecohistoria e historia medieval; 451-473. Cáceres, 2001.

TOLEDO TOLEDO, Manuel. Historia de la Villa y Tierra de Yanguas. Ed. Excma. Diputación Provincial de Soria, col.: TEMAS SORIANOS, 29. Soria, 1995. 


\section{Apéndice Documental}

1373, septiembre, 29. TOTICO.

Acuerdos alcanzados por los representantes concejiles de Muro de Aguas y Enciso en las yuntas celebradas entre ellos en la fecha.

Archivo Municipal de Muro de Aguas (B). Signat. P010/01. Cuadernillo de 15 hojas de papel de $220 \times 160 \mathrm{~mm}$. aprox. Falta la $1^{\text {a }}$ de ellas; fols. 2r.-5r. Traslado, realizado el 11 de noviembre de 1522, por Diego Martínez, escribano público de la villa de Enciso, y por Pedro Ramo, escribano público de la villa de Muro de Aguas, de las cartas de hermandad suscritas por los concejos de Enciso y Muro de Aguas en 1373 y 1422.

Archivo Municipal de Enciso (B). Signat. ENCI005/07. Libro de traslados de concordias y ordenanzas (siglo XVI). Muro. Fols. 25v.-35v.

[fol. 25v.] Sepan quantos esta carta vieren como nos, los conçejos de Ençiso e sus aldeas e de Muro de Entramasaguas e de sus aldeas, seyendo juntados en yuntas del nozedo de Totico, do es mojón que parte los terminos de los dichos lugares, según que lo avemos de uso e costunbre de nos ayuntar, otorgamos e conosçemos que por razón de tirar desacuerdos e daños, e contiendas e peleas, que acaesçen entre nosotros por razón de los dichos pastos e tajo de leña de monte en los nuestros términos, e por razón de los cotos, quieran declarar en tal manera que todos fuésemos bien avenidos e lo ${ }^{47}$ [fol. 2r.] pudiéssemos bien passar e vivir en paz y en sosiego nos e los que vernán en pos de nos en todos los tienpos del mundo, ordenamos [nos], los dichos conçejos, avenidament, esto que aquí se sigue:

Primerament, en razón de los pastos, que la cabaña de las ovejas e cabras de qualquier vezino o vezinos de Ençiso e de sus aldeas, en la matança que tajare en término de Muro, que aya de coto ocho maravedís, si fuere la cabaña de treynta reses arriba, e, dende a yuso, que aya de coto cada una res dos meajas de las que fazen seis un dinero.

Otrosý qualquier vezino o vezinos de Muro de Entranbasaguas e de sus aldeas que echare matança en término de Ençiso que aya este mesmo coto.

Otrosý los bueys e vacas de qualquier vezino o vezinos de Ençiso e de sus aldeas que aya de coto en la matança cada res dos dineros, e la vaca que saque su fijo que mamare; e los bueys e vacas de los vezinos de Muro que ayan esta misma pena en la matança que echaren en término de Ençiso.

E el pasto de de día que lo ayan suelto con sol, según que siempre lo ovieron los ganados de Ençiso e de sus aldeas en término de Muro e los ganados de Muro en término de Ençiso.

Otrosý [sy], por aventura, los ganados de los vezinos de Ençiso entraren en dehesa en término de Muro, de pan o de vino o de restrojos, que ayan de coto la cabaña de las

47. Hasta aquí el texto está tomado del Archivo Municipal de Enciso (B). Signat. ENCI005/07. Libro de traslados de concordias y ordenanzas. Fol. 25v. Desde aquí, del Archivo Municipal de Muro de Aguas (B). Signat. P010/01. Cuadernillo de 15 hojas de papel de $220 \mathrm{x}$ $160 \mathrm{~mm}$. aprox.; falta la $1^{\text {a }}$ de ellas; fols. 2 r.-5r. 
ovejas e cabras un carnero, si fueren de treynta reses arriba e, dende a yuso, que aya cada res un dinero; e la dehesa de los restrojos que sea fasta el día de Santa María de agosto en cada un año, e que comience el primero día de março en cada uno de los dichos términos de los dichos lugares; y el ganado mayor que [fol. 2v.] fuere tomado en estas dichas dehesas de los vezinos de Enciso que aya de coto cada res un dinero; e si alvergaren de noche en dehesa o fuera de dehesa en término de Muro que ayan esta mesma pena, e non más; e los ganados de los vezinos de Muro que ayan en término de Ençiso esta mesma pena en las dichas dehesas e fuera dellas, e non más; e, si daño fizieren en el pan los ganados de los vezinos de qualquier de los dichos lugares, que aya de pena el ganado menudo cada res un çelemín, e el ganado mayor cada res tres çelemines del pan en que fiziere el daño, o el apreçiamiento qual más quisiere el dueño del pan; [e] los puercos de qualquier de los dichos lugares que fueren tomados en estas dichas dehesas que ayan el coto según que el ganado menudo.

E si la cabaña de las dichas ovejas e cabras de los vezinos de Ençiso e de sus aldeas alvergaren de noche en término de Muro que aya de coto tres maravedís; e la cabaña de los vezinos de Muro que aya esta mesma pena si alvergare en término de Ençiso.

Otrosí en razón del tajo de los montes, qualquier vezino de Ençiso y de sus aldeas que cortare pie de faya, o de enzina o de robre, que aya de pena quatro maravedís; e por el cornal un maravedí; e por la carga de leña verde un maravedí; e esta mesma pena ayan los vezinos de Muro que cortaren en término de Ençiso.

E qualquier vezino que cortare e traxiere carga de ramón de los dichos lugares del término ageno que pague de pena quinze dineros; e por el faz de ramón çinco dineros; e por el palanco tres dineros.

La leña seca que la fagan e la lieven sin pena los vezinos de los dichos lugares del un término al otro; e de la fusta que sea para hazer aradros [fol. 3r.] o para menester de era e de labrar, por pan o por vino, que la cojan e la lieven sin pena los vezinos de Enciso de término de Muro e los vezinos de Muro de término de Ençiso.

Enzinas y landes e hoes, si las fallaren en tierra e las non avarearen, que las cojan sin calonia los vezinos de Ençiso o de sus aldeas en término de Muro, e los vezinos de Muro en término de Ençiso; e qualquier que las avareare que pague tres maravedís de pena e que pierda la carga de las que toviere cogidas; e todo otro monte menor que no se nombra en esta carta que lo corten e lo lieven sin pena los vezinos de Ençiso en término de Muro e los vezinos de Muro en término de Ençiso.

Otrosí en razón del portadgo, que el vezino de Ençiso que conprare qualquier cosa en Muro e en sus término que non pague portadgo, e el vezino de Muro de Entranbasaguas que aya essa mesma franqueza en término de Ençiso; e esto es porque fallaron que se avíe assí usado de siempre acá.

Otrosí todas las viandas que sean sueltas que las puedan conprar e levar los vezinos de los dichos lugares del un logar al otro.

Otrosí los deheseros que fueren puestos en qualquier de los dichos lugares para guardar las cosas sobredichas que sean puestos por un año, e juramentados; e [a] los ganados que non les vala fuída, salvo si arribaren a su término, que les vala.

E todas estas cosas que sobredichas son, e cada una dellas por sí, juramos e prometemos nos, el dicho conçejo de Ençiso a vos, el dicho conçejo de Muro. E nos, el dicho conçejo de Muro otrosí juramos e prometemos a vos, el dicho concejo de Enciso, de las 
guardar bien e lealmente e de las aver por firmes para agora e para siempre jamás, [fol. $3 v$.] e de nunca venir contra ellas nin contra alguna dellas en alguna manera nin por ninguna razón; e qualquier de nos, los dichos conçejos, que non guardássemos todas las cosas que en esta carta son escritas e cada una dellas, e las quebrantássemos en todo o en parte dellas, que cayamos en pena de diez mil maravedís.

E qualquier vezino de los dichos lugares que cayere en alguno de los cotos sobredichos de los pastos e tajos, e defendiere la prenda e non pagare a voluntad del dehesero el coto en que cayere e viniere sobre ello ante su alcalde, que lo pague con el doblo el coto en que cayere; e, por la pena de los dichos diez mil maravedís el conçejo que en ella cayere, que los alcaldes e ofiçiales que fueren por tiempo en el conçejo que en ella cayere, que puedan entregar e entreguen al conçejo a quien non fueren guardadas estas cosas sobredichas o a qui lo oviere de recaudar por él; e si, por aventura, los offiçiales que fueren por tiempo non entregaren de la dicha pena en bienes del conçejo que en ella cayere o de qualquier o qualesquier de sus vezinos, del día que les fuere requerido fasta veynte días siguientes, que, de este dicho plazo adelante, que el conçejo que oviere de reçebir la pena, o aquél o aquéllos que lo ovieren de recaudar por él, que se puedan entregar e se entreguen de los bienes del conçejo que en ella cayere e de qualquier o qualesquier de sus vezinos; e puesto que la dicha pena sea pagada, o non pagada, que todo quanto en esta carta se contiene que sea firme e valedero para agora e para siempre jamás; e porque todo esto sea firme e non venga en duda nos, los dichos conçejos mandamos a Martín Ferrándes, escrivano público del dicho conçejo de Ençiso, que estava presente, que escriviese desto dos cartas, tal la una commo la otra, e las signasse con su signo; e por mayor firmeza pusiemos en cada una dellas nuestros [fol. 4r.] sellos de çera pendientes.

E rogamos a Diego Álvarez, clérigo, e a Juan Christóval e a Gil Domínguez, e a Pascual Gil e a Martín Cordón, vezinos de Ençiso; e a Juan Gil e a Pero Çervera, e a Llorenti e a Martín Cabrarizo, vezinos de Muro; e a Pero Ruiz, fijo de Pero Ruiz, vezino de San Pedro, que fuessen dello testigos.

Fecha esta carta veynte y nueve días del mes de setiembre, Era de mil e quatroçientos e honze años.

E yo, Martín Ferrándes, escrivano público sobredicho, fui presente a todo lo que dicho es con los dichos testigos, e esta carta escreví e fiz aquí este mi signo en testimonio.

E otrosí dixieron que, por razón que era e avíe seído fasta aquí algunas vezes entre los dichos conçejos e vezinos dende duda e contienda sobre razón de la entrada del pasto, de día e con sol, a los dichos términos de los dichos lugares por los otros términos acomarcantes, si la devíen aver o non, por quanto no estava declarado por las dichas hordenanças, assí commo de los términos de Préxano y de San Pedro y de Vea; e los ganados de Muro y de sus aldeas al término de Ençiso, e los ganados de Ençiso y de sus aldeas al término de Muro, e tiraron la dicha duda e declararon que pudíen entrar de día e con sol los ganados de los dichos lugares de Ençiso e de Muro a los dichos términos de Ençiso e de Muro, e a qualquier dellos, por los dichos términos acomarcantes de Préxano e de San Pero e de Vea, e paçer las yervas e bever las aguas de día e con sol, sin coto e sin caloña alguna, non faziendo daño en los panes e viñas, ni en las cosas por las dichas ordenanças acotadas, e que sopieran verdad que siempre lo usaran assí los dichos conçejos de Ençiso e de Muro; e que firmavan e firmaron entre sí el dicho uso e costunbre para siempre jamás, sin duda alguna; e prometieron [fol. 4v.] de non venir contra el 
dicho uso e costunbre en razón de la entrada de los dichos pastos por sí nin por otri, agora nin en algún tienpo del mundo; e si contra ello viniessen o asintiessen venir, qualquier de los dichos conçejos, que cayessen e caya por ello en la pena de los dichos diez mill maravedís por las dichas ordenanças contenidos, por cada vegada; e la dicha pena pagada, o non, que el dicho uso y costunbre siempre sea firme e vala; e renunciaron e quitaron de sí toda lei e todo fuero e toda costunbre escrito e por escrevir de que se pudiessen ayudar para venir contra ello o contra parte dello.

E otrosí declararon que la Dehesa de los Huertos de arrededor ${ }^{48}$ de la aldea de Entrambasaguas, término del dicho lugar de Muro, que sea guardada, según que la ovieron acostumbrada.

E estos dichos declaramientos fechos sobre las dichas dudas dixieron que mandavan e mandaron a nos, los dichos escrivanos, que los ayuntássemos a las dichas hordenanças que fueron fechas ante, e fiziéssemos dos cartas dello para los dichos conçejos, tal la una commo la otra, e que sean signadas e selladas en la manera sobredicha; que há el sello de nos, el dicho conçejo de Ençiso, una figura de león en campo blanco e castillos en derredor; e que há el sello de nos, el dicho conçejo de Muro, una figura de castillo e dos lobos ençima dél que se catan de rostro a rostro.

Testigos que fueron presentes Juan Benito e Per Elvira, e Pero Çebrián e Rodrigo, fijo de Diego Álvarez, e Gil, fijo de Ximén Martínez, vezinos de Ençiso; e Martín Abad e Martín Ferrándes el Coxo, e Martín, fijo de Juan Alcaraz, vezinos de Muro.

E yo, Domingo Ferrándes, escrivano público sobredicho, fuy presente a todo lo que dicho es con los dichos testigos, e, por ruego e mandamiento de los dichos yunteros, en boz y en nonbre de los dichos conçejos, escreví esta dicha carta en la manera que [fol. 5r.] dicha es, e fiz en ella este mi signo en testimonio de verdad.

Domingo Ferrándes.

E yo, Fernán Martínes, escrivano público sobredicho, fui presente a todo lo que dicho es con los dichos testigos, e, por ruego e mandamiento de los dichos yunteros, en boz y en nonbre de los dichos conçejos, fiz aquí este mi signo en testimonio de verdad.

Fernán Martínes.

E yo, Martín Ferrández, escrivano público sobredicho, fui presente a todo lo que dicho es con los dichos testigos, e, por ruego e mandamiento de los dichos yunteros, en boz y en nonbre de los dichos conçejos, fiz aquí este mi signo en testimonio de verdad.

Martín Ferrándes.

1383, enero, 27. LA VARGUILLA.

Acuerdos logrados por los representantes concejiles de San Pedro Manrique y Muro de Aguas en la yunta que celebran en esta fecha.

48. Alrededor, en torno a. 
Archivo Municipal de Muro de Aguas. Signat. P01/02. Perg. 258 × 290 mm. Aprox. Roto, borroso, con abundantes faltas de perg. que dificultan la lectura de buena parte del texto del doc. (A).

Archivo Municipal de Muro de Aguas (B). Signat. P208/10. Traslado notarialmente compulsado el 24 de mayo de 1705 por Pedro Francisco Cabello Martínez, escribano del número de la villa de Muro de Aguas, y por Prudencio Ximénez Tendrón, escribano del número de la villa de San Pedro Manrique. En la transcripción, el texto del doc. está en cursiva (B).

[fol. 1r.] Sepan quanttos esta carta vieren como nos, el concexo de Sanct Pedro, y como nos, el concexo de Muro de Enttranbasaguas, esttando ayunttados <en las yunttas $>$ encima de la Varga de Enttrambasaguas, entre término de Sant Pedro y de Muro, do lo han de yuso y de costtunbre de se ayunttar hombres buenos de los dichos concexos, en razón de los pasttos y de los taxos de los montes, y de las aguas que han de beber los ganados; ottrosí en razón de los añales, fallaron que de uso de siempre acá estto que se sigue:

Enttre los concexos de Vea y de Muro, lo primero que qualquier que pasare a morar de los unos términos a los otros, que pase con su añal y que saque por cada año un añal; y que por el añal que pague seis almudes de trigo y seis almudes de cebada y tres maravedís en dineros; e que non libren otro pecho alguno, porque fallaron por hombres buenos de los dichos concexos que siempre se usó assí desque memoria de hombres entre vivos acá non es en conttrario.

Ottrosín que los tales vecinos que pastan con su añal que non sean prendados [fol. 1 v.] por deudas nin por prendas, ni por ottra cossa alguna que enttre los dos concexos fuere, salvando por su deuda propria.

Ytten esttos añales, los ganados con que labraren, [e con] que coxieren el pan o el vino o qualquier de dichos frutos, que los puedan traeer en qualesquier de los dichos términos, de noche e de día, do pacieren los ottros sus ganados de cada uno de los dichos concexos.

Ottrosí, en razón del pasto de los ganados, que puedan pacer en todo lugar en todos los dichos términos, guardando pan e vino e dehessas acosttunbradas, y que beban las aguas con sol, tornándosse cada uno a sus términos a yaser con sol a qualquier de los dichos términos; y sin sol por amajadando de noche que aya de pena una res, la qual tomare el dehesero; e la di-[cha] res que la non maten fasta el terçero día; e del buey e de la yegua que aya, por cada cabeça mayor, un dinero; e de las dehesas acotadas que ayan la caloña doblada; e del daño que fisieren en el pan, o en vino o en las viñas, que aquél o aquéllos que lo fisieren que lo paguen a sus dueños, e que quede en escogençia del señor del que reçibiere el daño de levar las maquilas o el apreciamiento quel más quisiere.

E las maquilas que sean en esta manera: de la res mayor, del día que fuere senbrada la pieça fastal primero día de março, que pague çelemín e [m-]edio del pan que fuere senbrada la pieça, e dende adelante, fasta que el pan fuere cogido, que pague cada res mayor tres çelemines de aquel pan; e que esta dicha caloña de pan que la pague fastal día de Sant Gil primero viniente. 
E, en rassón de los ganados menudos, que del día que fuere senbrada fastal primero [d-]ía de março, que pague, fasta trenta cabeças, que paguen por cada una cabeça un dinero e, de trenta cabeças arriba, que se entiende seer cabaña, que pague por cada cabaña un carnero; e sy, por aventura, mayor fuere el daño que la dicha caloña montare, que sea a bien vista de buenos omes; e del día primero de março adelante que pague por cada una cabeça del dicho ganado menudo un çelemín del pan que estudiere senbrada la pieça do fisiere el daño; e la dicha caloña de los dineros que la pague luego o den prenda por ello e, sy non, que puedan prendar del dicho ganado segúnt de suso se contiene; e del pan que lo pague al dicho día de Sant Gil; e que sean tenidos danbos dichos conçejos de dar dos omes buenos para que sean casa con peños ${ }^{49}$, pero, en cada año, el uno que sea de Entrambasaguas, por la parte de Muro, e, el otro, que sea de Armejún por la parte del conçejo de Sant Pedro.

Otrosý en rasón de los tajos de los montes, que qualquier que cortare pied de robre o de carrasco que se pueda quadrear para madera de casa o para pie, que pague por cada uno quatro maravedís; e de los otros tajos que pague por cada pie dos dineros e medio.

E que las dehesas entre los dichos conçejos que sean guardadas desde el primero día de março fasta Santa María de Agosto, cada año.

E sy algunos defendieren las prendas a los deheseros, de la una parte o de la otra, que aya la caloña doblada e que vayan al pueblo donde fuere el ganado cada uno a la casa con peños; e sy non le quisieren entregar de prendas que pueda prendar de bienes del conçejo sin caloña alguna; e sy yuntas ovieren de aver los dichos conçejos, o costas se recrecieren sobre la dicha rassón, que las paguen aquél o aquéllos que fallaren que fisieron la dicha sinrasón; e las dichas prendas o requerimientos que se puedan faser fasta terçero día, e, sy non se fisieren en el terçero día, dende adelante que non puedan seer demandadas las dichas caloñas, salvo las que fueren requeridas o [pren-]dadas, segúnt dicho es.

E otrosý de la matança del ganado menudo, de trenta reses arriba de qualquier monte, que aya un carnero, e del carnero que aya tres maravedís ${ }^{50}$; e de trenta ayuso de cada res dos dineros; e de la matança de bueyes e vacas que aya de cada res dos dineros; y de la carga de ramón un maravedí, y de el faz çinco dineros, e del palanco tres dineros, en qualquier término de los dichos concexos; ;e si, por aventura, los panes no fuesen cogidos fasta el día de Santa María de agosto e acarreados, que lo fagan saver un conçejo al otro, para que se guarden las dehesas fasta que los panes sean acarreados.

E de esto mandaron faser dos cartas eguales, tal la una como la otra, [fol. 4r.] signadas de Sancho Sánchez, escrivano público de la dicha villa de Sant Pedro, e de Ferránt Martínes, escribano público de Muro, e que sean selladas cada una de las dichas dos cartas con los seellos de los dichos conçejos; e todo esto ordenaron porque fallaron hombres buenos de los dichos conçejos que pasó asý e obligándose ambos, los dichos concexos, de lo assí tener y cumplir e guardar para agora e para siempre jamás, so pena de cinco mill maravedís para la parte obediente; $y$, pagada la dicha pena o non pagada, toda vía que las dichas cartas de condiciones que sean fixas e valideras para agora y para en todo tiempo.

49. Para que tomen las prendas que correspondan de su casa.

50. Dineros. 
Testigos que a esto fueron presentes de la villa de Sanct Pedro y de sus términos Joseph Remírez y Martín Rodríguez, y Gil [fol. 4v.] Péres de Millán, e Fernánd Ximénez y Joseph de las Heras y Thomás Martínez y Pedro Ximénez, vecinos de Sanct Pedro; e de la villa de Muro, Martín Gonçáles e Diego González y Pedro Domingo y Sancho Fernández, vecinos de Muro.

Y es fecha esta dicha carta en la dicha Varga, a vente e siete días de henero, Era de mill quatrocientos y veinte e un años.

\section{3}

1390, junio, 16.

Acuerdos alcanzados por los concejos de Muro de Aguas y Préjano sobre el aprovechamiento de sus términos comuneros en la junta que celebran entre ellos.

Archivo Municipal de Muro de Aguas. Signat. P01/01. Perg. (480?) x 390 mm. Aprox. Dos trozos de perg., hoy separados y rotos, con muchas zonas borrosas y con abundantes faltas de perg. que dificultan la lectura de buena parte del texto del doc. que contienen $(A)$.

Sepan quantos esta carta vieren commo nos, el conçejo de Muro e de Entranbasaguas, e commo nos, el conçejo de Préxano, seyendo ayuntados en la Sierra del Focijo, en el logar [do se] parten los términos de nos, los dichos conçejos, otorgamos e conocemos que por raçón de tirar de nos contiendas e daños, e malas peleas que se acahecían dentre nosotros por [raçón de los pas-]tos e tajos e leña del monte en los nuestros términos; e por rasón de los cotos que era mester mejorar e allegar, en tal manera que todos fuésemos bien abenidos e lo podiésemos [con bien] passar, e las buenas amistanças e los buenos amoríos levar adelante, e por bevir en paz e en sesiego agora e en todos tiempos del mundo para siempre jamás, hordenamos leal hermandad en esta manera que aquí se sigue:

Primeramente, la caloña de las ovejas e cabras de qualquier vezino o vezinos de Muro e de Entranbasaguas en la matança que tajare en término de Préxano que aya de coto un carnero, sy fueren de trenta reses arriba e, dende a yuso, cada una res que aya de coto dos meajas.

E otrosý qualquier vezino o vezinos de Préxano que echare matança en término de Muro e de Entranbasaguas que aya ese mesmo coto que es dicho de los vesinos de Muro e de Entranbasaguas.

E otrosý los bueys e las vacas de qualquier vezino o vezinos de Muro e de Entranbasaguas que ayan de la matança que cortaren en término de Préxano cada una res dos dineros; e la vaca que saque su fijo que mamaren.

E otrosý qualquier vezino o vezinos que echaren matança a bueys o a vacas en término de Muro e de Entranbasaguas quel aya el coto sobredicho.

E otrosý la carga de leña verde que cortaren qualquier [vezino o vezinos de Muro e de Entranbasaguas en término de Préxano] que aya de coto un maravedí. 
E otrosý la carga de ramón que aya de coto ocho dineros, el fus ${ }^{51}$ de ramón quatro dineros, el palanco dos dineros; e qual coto ovieren los vezinos de Muro e de Entamasagus en los términos de Préxano de leña e ramón que esse mesmo ayan los vesinos de Préxano en término de Muro e de Entranbasaguas ...

[E otrosý qualquier vezino de Muro e Entran-]basaguas que tajare pied verde en término de Préxano que aya de coto dos maravedís, e este mesmo coto ayan los vezinos de Préxano en término de Muro e de Entramasaguas.

... Otrosý toda fusta que sea para aradro o para casa que la puedan ... vezinos de Muro e Entranbasaguas e las ... dicho día de Sant Martín que ... cada res dos meajas e ...

... [de-]hesa o fuera della, e este mesmo coto que ayan los ... Préxano.

Et otrosý qualquier vesino de Muro e de Entranbasaguas ... esso mesmo que fagan los vesinos de Préxano en el término de Muro e de Entranbasaguas ...

[Otrosý si algunos vecinos de qualesquier de nos, los dichos conçejos, traxeren ganados algunos ajenos con los nuestros], que puedan los deheseros de qualquier de los dichos conçejos tomar carnero o carneros en [las cabañas onde ovieren sospecho que anada ganado ajeno, cada uno en] su término.

E sy los defeseros ovieren sospecha que [el tal] ganado ajeno anda en qualquier de las cabañas quel [puedan demandar jura, según forma de derecho, antel alcalde del] logar onde fuere levado el carnero; e, sy non quisiere el pastor fazer la jura, que pague el carnero por cada vegada que asý fuere ... pero que ... e los defeseros, fasta que el pastor faga la jura; e sy la non quisier fazer fasta nueve días que fuer tomado el carnero, que lo pue[-da] lograr.

[Otrosý que] qualquier ganado vacuno que entrare en el pan de qualquier vesino de los dichos lugares que aya de coto, fasta el primer día de março, cada una res dos dineros.

Otrosý [que qualquier ganado menudo que] entrare en el pan, commo dicho es, ante de março, que [aya ca-]da res un dinero, fasta trenta; e de trenta arriba carnero.

Otrosý las dehesas que cada uno [que cada uno de nos, los] dichos [conçejos, echáremos] cada uno en sus términos commo son acostumbradas, que seamos tenudos a las guardar los unos a los otros desde el primero día de março fasta el día de Santa María de ag[-osto]; e qual[-quier que] en ella entre que aya el coto sobredicho.

E otrosý qualquier [ganado] menudo que entrare en el pan en qualquier término de nos, los dichos conçejos, que aya de coto cada una res un çelemín del [fruto] que fuer el senbrado que entrare do se fiziere el daño, [o el apresçimien-] to quel más quisisere el dueño del pan.

E otrosý, sy buey o vaca o bestia de los vezinos de qualquier de nos, los dichos [con]çejos, entrare en el pan en qualquier de los dichos tér[-minos, que aya de coto] cada una res tres çelemines de pan del fruto que fuere el senbrado do se fisiere el daño, o el apresçimiento quel más [qui-]siere el dueño del pan.

51. El fas, es decir, el haz o gavilla de ramón. 
E otrosý en rassón de los [cotos que sobredichos son], que qualquier de nos, los dichos conçejos, o qualquier vezino o vezinos de los dichos conçejos de Muro e Entranbasaguas e Préxano, que fuere rebelde en no lo pagar, o defendiere la prenda [que en ] esta rasón fuere tomada, que los ofiçiales que fueren por tiempo en qualquier de los dichos logares sean tenudos, so la pena que en esta carta será contenida, de les dar e entregar de todo lo que asý fuer anparado con el doblo del rebelde en el logar do fuere dada la querella sobre esta rasón.

E otrosý, en rasón de las viandas, que los vezinos de Muro e Entranbasaguas que las puedan conprar en Préxano e en su término, e sacarlas e levarlas, asý pan e vino e carne, muerta e biva, e todas las otras cosas que se pueden conprar e vender.

E otrosý que los vezinos de Préxano puedan conprar e sacar todas las viandas que sobredichas son de Muro e d'Entranbasaguas e de sus términos.

E otrosý, sy vos, el conçejo de Muro e de Entranbasaguas, ovierdes mester acorro de conpañas, que seamos tenudos de vos acorrer de la más conpaña que pudiermos do fuéremos Ilamados de vos, el dicho conçejo.

E otrosý, sy por aventura, vos, el dicho conçejo de Préxano, ovierdes mester acorro de conpaña, que nos, el dicho conçejo de Muro e de Entranbasaguas, que seamos tenudos de vos acorrer con la más conpaña que podiermos do fuéremos llamados de vos, el dicho conçejo de Préxano.

E otrosý que vos, el dicho conçejo de Muro e d'Entranbasaguas, que podades pasçer las yervas e bever las aguas, guardando pan e vino e las dehesas que fueren echadas, segúnd dicho es, con sol, en el término de Préxano, fasta çima de la Sierra de Santiváñes, fasta suelo de [barran-]co de Arapita, e como tiene el Camino de Andancha barranco arriba, e como tiene el Vallejo de Canales e a la Fos de Canales e a la Tonda aquendera $^{52}$; e esto guardando las dehesas e con sol, segúnd dicho es.

E otrosý que vos, el dicho conçejo de Préxano, que podades pasçer las yervas e bever las aguas con vuestros ganados en los términos de Muro e de Entranbasaguas con sol, guardando pan e vino e las dehesas que fueren echadas, segúnt dicho es, del Cabeço la Runanda a los Angostiellos, e para el Cabeço de sus del aldea, e para el Collado Micolays, e para el sendero que va a los Villares, e por el sendero que atraviessa por las Sernas fasta la Llana Montalén e al Colladiello ( $\ldots$... fasa?), e al Cabeço Menga Ruvia e al Poso Johan Navarro e a la Peña de Somo el Prado de Navatiello.

E otrosý qualquier que livare las maquilas o el apresçiamiento del pan que aquél pague a los deheseros e jurados por cada res dos dineros; e los deheseros que fueren puestos que les tomen jura en cada conçejo; e desque asý ovieren jurado que sean creýdos en su [ofiçio] por el dicho de su palabra confirmando la jura que fizieron.

E otrosý ordenamos que ninguno nin alguno de nos, los dichos conçejos, que non seamos tenudos de reçebir ninguno nin alguno vezino nin vecinos, [por pastos] nin por yazijas, en los términos de nos, los dichos conçejos, e de qualquier de nos; salvo por morada, en qualquier de los dichos logares, afirmando casa continuadamente en qualquier de los dichos logares Muro e Entranbasaguas e Préxano, do recibiere la dicha vecindad.

52. La Tonda -el montículo con forma redondeada- que está del lado de acá. 
E todas estas cosas e cada una dellas que sobredichas son juramos e prometemos nos, el dicho conçejo de Muro e de Entranbasaguas a vos, el dicho conçejo de Préxano. E otrosý nos, [el dicho conçejo de Préxano], prometemos a vos, el dicho conçejo de Muro e Entranbasaguas, de las guardar bien e lealmente, e de las aver por firmes para agora e para sienpre jamás, e de nunca venir contra ellas nin contra alguna dellas en ninguna manera; e qualquier de nos, los dichos conçejos de Muro e Entranbasaguas e Préxano, que non guardásemos todas las cosas que en esta carta son escriptas, e cada una dellas, e las quebrantásemos en todo o en parte dellas, que cayamos en pena de diez mille maravedís al conçejo a quien non guardásemos todas e cada unas de las cosas que en esta carta son escriptas; e desta pena sobredicha nos, los dichos conçejos de Muro e Entranbasaguas e de Préxano, damos poder a los ofiçiales que fueren por tienpo que puedan entregar e entreguen cada unos en sus logares de la dicha pena al conçejo a quien non fueren guardadas estas cosas e cada una dellas, o aquél o aquéllos que lo ovieren de recaudar por él; e sy, por aventura, los ofiçiales que fuessen por tienpo non quisiesen entregar de la dicha pena en bienes del conçejo que en ello cayere, desdel día que les fuer requerido fasta vente días siguientes, que, deste plazo adelante, quel conçejo que oviere de reçebir la pena, o aquél o aquéllos que lo ovieren de recaudar por él, que se puedan entregar por sý de los bienes del conçejo que en la dicha pena cayere e de sus bienes; e puesto que la [dicha pena fuere] pagada, o non, que todo quanto en esta carta se contiene que sea firme e valedero para agora e para sienpre jamás.

E otrosý quando algunas cosas fueren mester de librar por la yunta, que los dichos conçejos que lo fagan saber por su carta el un conçejo al otro, que le salgan a yunta hý do lo an de huso e de costunbre onbres buenos de los dichos conçejos; e qualquier que fuer rebelde e non quisiere salir a yunta que peche en pena vente maravedís a la parte que viniere; e esa pena que la enbíen demandar una vez a los que en ella cayeren, e sy non ge la pagaren del día que les fuere demandada fasta terçero día, que ellos por sý se puedan entregar.

E porque esto sea firme e valedero, segúnd que sobredicho es todo, mandamos a vos Martín Ximénez, e a vos, Ferránt Martínez, escrivanos públicos que estades presentes, que escrivades esta carta e la signedes de vuestros signos, en la qual nos, los dichos conçejos, pusiemos nuestros seellos de çera pendientes, de lo qual rogamos a Yváñes Domingo e a Pero Sánches e a Martín Ferrándes Coxo, vesinos de Muro de Entranbasaguas, e a Johan Ferrández Ezquerro e a Johan Ferrández e a Gil Péres, juez, e a Miguel (Sánchez?), vesinos de Préxano, que sean dello testigos.

Fecha sese días de junio, año del nasçimiento de nuestro salvador Ihesu Christo de mille e trezientos e noventa años.

E yo Ferránt Martínes, escrivano público de Muro sobredicho, que fuy presente a lo que sobredicho es con los dichos testigos, e por rueg[-o e mand-]amiento de los dichos conçejos, esta carta escriví para el conçejo de Muro e Entranbasaguas; e el dicho Martín Ximénes otra tal para el dicho conçejo de Préxano; e en ella fiz mi sig[-(signo)-]no en testimonio de verdat.

Ferránt Martínes (rubricado).

E yo, Martín Ximénes, escrivano público de Préxano sobredicho, que fuy [present-]e a lo que dicho es con los dichos testigos, e por mandado de los dichos conçejos, esta 
carta [fesimos] e signamos, e yo e el dicho Ferránd Martínes, e por ende fis aquí este mio sig[-(signo)-no] en testimonio de verdad.

Martín Ximénes (rubricado).

1392, abril, 8. TOTICO.

Los yunteros de los concejos de Muro de Aguas y Enciso piden a los alcaides de los castillos que no les cobren pasaje y castellería a sus rebaños, pues lo tienen así por uso y costumbre acordado entre ellos y reconocido por sus respectivos señores.

Archivo Municipal de Enciso (B). Signat. ENCI005/07. Libro de traslados de concordias y ordenanzas. Fol. 29r.-30r. Muro. Hermandad. Castillería.

[fol. 29r.] Lunes, ocho días de abril, año del nacimiento de nuestro salbador Ihesu Christo de mill e trezientos e noventa e dos años.

Este día, seyendo en yunta çerca del nozedo de Totico, que dizen do es el mojón e que departe los términos de la villa de Ençiso e de la villa de Muro e Entramasaguas, seyendo ý de la parte de la villa de Ençiso e del conçejo dende por yunteros Diego Álbarez, cura, e Martín Domínguez, alcalde; e de la parte e la dicha villa de Muro e del conçejo dende por yunteros Garçi Ruiz, caballero, e Ivánes Domingo, alcalde, e Pero Sancho; en presençia de mí, Martín Fernándes, escribano público de la dicha villa d’Ençiso, e de mí, Fernán Martínez, escribano público de la dicha villa de Muro; e de los omes buenos que aquí serán escritos por testigos; e los dichos yunteros dixeron que por razón que los ganados de los dichos logares algunos tiempos e sazones avían de salir a ervajar e guaresçer con sus neçesidades fuera de los dichos términos, e los alcaydes de los castiellos de los dichos logares dizían que avían de aver della quando pasaban en la dicha manera a otros términos carnero e borra de pasaje e castellería, de cada cabaña de ganado; e que lo pidían e, algunas vezes, que ponían e avían puesto enbargo en el paso a los dichos ganados por la dicha castellería; e dixieron que por razón que los dichos conçejos avían pasto en los dichos términos, unos con otros con sus ganados [fol. 29v.] de día e con sol, e lo ovieran ansí suelto sin coto e sin calonia en todo tiempo, según que lo avían firmado por sus cartas de abenençias e ordenanças que sobrello tenían, e que los dichos alcaydes pedían e pidieron el dicho castellaje sin derecho, e que lo non podían aver, pues los dichos conçejos avían entre sí las dichas abenençias y el dicho pasto suelto; e por ende dixieron ellos en nombre de los dichos conçejos, asý como sus yunteros, [que] se obligaban e obligaron, los unos a los otros e los otros a ellos, de guardar por sí e por sus vezinos cada uno e su lugar e término, e al alcayde dende, que no sean tomados ni enbargados los dichos ganados por la dicha razón del dicho castellaje en algún tiempo del mundo; e si, por aventura, no lo pudiesen por sí desvíar e los alcaydes o alcayde quisiesen o quisiese fazer fuerça sobrello, que sean tenidos a les rogar e requerir sobrello que les non pasen ni les consientan pasar contra las sus buenas avenencias e ordenanças que avían entre sí en la dicha razón; e si lo non quisisesen dexar, que sean tenidos los del logar donde acaesçiere de lo mostrar e querellar al señor en 
como su alcayde les quebranta los sus buenas abenençias que an entre sí los dichos conçejos, e que farían e guisarían en manera que todo esto fuese guardado ansí; e dixieron que deste asentamiento que fazían entre sí, en voz y en nonbre de los dichos conçejos, que mandavan e rogaban a nos, [fol. 30r.] <Muro, final conposiçión $>^{53}$ a nos ${ }^{54}$, los dichos escribanos, que lo diésemos por testimonios signados con nuestros signos a cada una de las dichas partes el suyo, tal el uno como el otro.

E a Martín Abad, vezino de Muro, e a Domingo Andrés, vezino d’Ençiso, que estaban presentes, que fuesen dello testigos.

E yo, Martín Fernández, escribano público, e yo, el dicho.

5

1422, septiembre, 27. ENCISO / MURO DE AGUAS.

Acuerdos alcanzados por los concejos de Muro de Aguas y Enciso.

Archivo Municipal de Enciso. Perg. 570 x 400 mm. aprox. Lleva restos de tres sellos de cera pendientes. Con algunas faltas de perg. (A).

Archivo Municipal de Muro de Aguas (B). Signat. P010/01. Cuadernillo de 15 hojas de papel de $220 \times 160 \mathrm{~mm}$. aprox.; falta la $1^{\text {a }}$ de ellas; fols. Traslado, realizado el $11 \mathrm{de}$ noviembre de 1522, por Diego Martínez, escribano público de la villa de Enciso, y por Pedro Ramo, escribano público de la villa de Muro de Aguas, de las cartas de hermandad suscritas por los concejos de Enciso y Muro de Aguas en 1373 y 1422.

Archivo Municipal de Enciso (C). Signat. ENCI005/07. Libro de traslados de concordias y ordenanzas. Fol. 30r.-35v. Muro.

Sepan quantos esta carta de hermandad et de tracto et de composición vieren commo nos, el concejo e alcaldes e oficiales e omes buenos de la villa de Ençiso e de sus aldeas, nonbradamente Martín Fernández e Diego Fernández, alcaldes, e Pero Ximénez, juez, e Fernán Ximénez e Garci Martínez, escrivanos, e Domingo Fernández del Villar e Pero Marín, e Johan Castiello e Johan Christóval, e Johan Yváñes de Garranço e Pero Fernández de Calahorra, e Pero Gil e Pero Martínez de las Ruedas, e Pascual Martínez de Valdevigas e Pero Martínez Azero, e Martín Ximénez e Gil Martínez Rodero, e Gil Martínez Tomás e Martín Fernández Ferrero, e Johan Estevan e Gil Martínez de la Caleja, e Pero Benito, seyendo ayuntados en nuestro concejo acerca de la yglesia de Santa María de Ençiso, a pregón llamados e a canpana repicada, según que lo avemos de uso e de costunbre de nos ayuntar. Et commo nos, el concejo, alcaldes, oficiales e omes buenos de la villa de Muro de Entranbasaguas, nombradamente, Rodrigo Ramo, alcalde, Domingo Ximeno, tenientelugar de alcalde, e Gil Martínez, juez, e Vicen Pérez e Miguel García, jurados, e Martín Pérez e Miguel Pérez, e Goncalo Llorenti e Diego Gonçález, e Pero Sánchez de Goroçi e Martín Gil, e Rui Díaz e Fernán Sánchez, e Diego Sánchez e Juan

53. En la parte superior de la página, fuera de la caja de escritura.

54. Repetidas las palabras: a nos. 
Fernández, e Johan Moreno, seyendo ayuntados en nuestro conçejo en suelo del Valliejo de Muro, e a campana repicada, según que lo avemos de uso e de costunbre de nos ayuntar, otorgamos e conoscemos que por tirar discordias e daños, e contiendas e males, e peleas e desacuerdos, e variaciones que acaecían e podrían acaecer entre nos, los dichos concejos e vezinos dende; e por aver paz e concordia, e acrecentar los buenos amoríos e buenas amigancas que son entre todos los buenos hermanos christianos e vecinos, a servicio de Dios e de Santa María e de toda la corte celestial; e otrosí a servicio de los señores que agora son e serán de aquí delante de nos, los dichos concejos, a quien Dios mantenga al su servicio, e a pro e honrra de nos, los dichos concejos e vezinos dende, que agora son e serán de aquí adelante fasta la fin del mundo, establecemos e ordenamos, e ponemos entre nosotros firme paz e leal e buena hermandad non revocable para en todos los tiempos del mundo, en la manera que se sigue:

Primeramente, ordenamos que la Dehesa de los Huertos, que es a derredor de la aldea de Entranbasaguas, que tenga e sea por donde está mojonada; e que sea guardada de todos e qualesquier ganados mayores e menores, e que non sean osados de entrar en la dicha dehesa nin en parte della ningunos nin algunos de los dichos ganados de los vecinos de Enciso e de sus aldeas. E la manada de ganado ovejuno e cabruno que en ella entrare e fuere tomada en la dicha dehesa, que fuere de treynta cabeças e dende arriba, que pague de pena por cada vegada un carnero, e dende a yuso, cada cabeça un cornado; e los bueys e bacas, e yeguas e rocines e bestias mulares, e asnos e asnas e sus semejantes que fueren tomadas en la dicha dehesa, que aya de pena cada cabeça un maravedí; et los fijos e fijas de todos estos ganados sobredichos que, mientre que mamaren, que non ayan pena alguna; e la manada de los puercos e puercas que fueren de veynte e çinco cabeças arriba que ayan de pena doze maravedís e, dende ayuso, cada cabeca media blanca, e que les non vala foýda en esta dicha dehesa a los dichos ganados [en] el dicho término de Muro, moviéndose luego el dehesero jurado que fuere a las tomar assí commo las veyere.

Otrosí ordenamos que todos los dichos ganados mayores e menores de qualquier nación que sean e qualesquier dellos de todos los vezinos de la dicha villa de Enciso e de sus aldeas, e de qualesquier dellos, que puedan entrar e entren al dicho término de Muro e de Entrambasaguas e a qualquier parte dél a paçer las yervas e a bever las aguas, de día e con sol fasta la noche, sin pena, guardando panes e viñas e dehesas acostunbradas por los términos de Préxano, e de Sant Pedro e de Vea, e de la dicha villa de Enciso, e por qualquier parte dellos.

E otrosí que puedan sallir los dichos ganados e qualesquier dellos del dicho término de Muro e de qualquier parte dél a los dichos términos de Sant Pedro e de Vea, e Préxano e Ençiso sin pena, de día con sol fasta la noche, pero que no puedan entrar nin entren los dichos ganados nin algunos dellos de los vezinos de Enciso e de sus aldeas el pago que dizen de las Sernas e de los Villares, a la parte de yuso fasta el agua de Vallaroso, de commo comiença el Collado Nicholás e va por el poyo de las pieças e recude a la mata que está en medio de la Honbría, e va de aquella parte del Varranco que dizen de Fuentepenilla e salle por medio de la pieça que es agora de Fernán Gorio ${ }^{55}$, de Préxano, e

\footnotetext{
55. Fernán Garrido, en B y C.
} 
recude a la mata que está en somo de la dicha pieça en la veta de la peña yusana, e dende adelante commo va derecho al somo de la pieça de los Villares, que es de Rui Díaz, que fue de Pero Fernández de Ocón, vezino de Ençiso; e va de aquella parte de la foya agua vertiente arriba al cabeço de somo de la Solana, que dizen de la Roça, e a somo del Cabeço de Çayna, e dende recude cerrillo ayuso al Portellejo de Molar, e va Camino arriba adelante de Arnedo fasta la passada del agua de Valdemuertos, e dende el agua arriba fasta el mojón de Préxano; e que non puedan passar nin passen dende adelante faz[-i-]a la parte de la villa de Muro desta parte de la dicha agua de Vallaroso; pero que la dicha agua de Vallaroso, fuera de la dicha Dehesa de los Huertos, que la puedan bever los dichos ganados de los dichos vezinos de Enciso e de sus aldeas sin pena, passando los dichos ganados de la una parte a la otra del agua según es necessario para bever, non se desapoderando los dichos ganados todos que ansí entraren a bever la dicha agua faza la parte de las dichas Sernas e los Villares.

Et que en esta dicha tierra e dehesa, según de suso es dicho e nonbrado, ni en parte della, que los dichos ganados ni alguno dellos de los dichos vezinos de Enciso e de sus aldeas que no puedan entrar nin entren, de día ni de noche en ningún tiempo del mundo, a paçer las yervas e bever las aguas; e, si entraren, que pague la manada de las ovejas e cabras que fuere tomada por los dichos deheseros jurados en la dicha tierra e dehesa o por qualquier dellos, que fueren de treynta cabeças e dende arriba diez maravedís por cada vegada, e dende ayuso cada cabeça un dinero; e los bueys e vacas, e yeguas e rocines e bestias mulares, e asnos e asnas e sus semejantes, que fueren tomados en la dicha dehesa, que pague cada cabeça una blanca; e los puercos e puercas que fueren tomados en la dicha dehesa que, si fueren treynta cabeças e dende arriba, que paguen de pena diez maravedís, e, dende ayuso, cada cabeça media blanca; et que los fijos e fijas destos dichos ganados que, en tanto que mamaren, que non ayan pena.

E que en esta dicha dehesa e tierra, según dicho es de suso, que ningún vezino de Enciso e de sus aldeas que non puedan coger nin avarear enzinas nin landes, e qualquier que lo fiziere que pague de pena cada perssona dos maravedís e demás que pierda las enzinas que toviere cogidas y el costal en que las toviere; e estos dichos cotos sobredichos de las dichas dehesas que se entiendan y sean también para de noche commo para de día.

Otrosí ordenamos que quando acaeciere que algún vezino de Muro e de Entrambasaguas fallare alguna pieça suya sembrada dañada e comida de algunos ganados, e oviere sospecha que ganados de vezinos de Enciso e sus aldeas ayan fecho el dicho daño, que pueda pidir et demandar a boz e a sospecha ante los alcaldes de Ençiso a tres o a quatro personas e non a más de los vezinos de Enciso e de sus aldeas a quien entendiere que él há la dicha sospecha, e que los dichos alcaldes apremien luego a los tales aplazados a fazer la dicha salva por el dicho su ganado, e si fazer no la quisieren que sean tenudos de pagar el daño que assí fuere fecho por apreciamiento de dos buenos homes del lugar donde fuere la dicha heredad, sobre juramento que sobre ellos primeramente fagan; e que esta dicha sospecha aya lugar de se demandar dentro en los nueve días, del día que fallare fecho el dicho daño, e non después; e que esta dicha ordenança se entienda assí el daño que fuere fecho en las viñas commo en los dichos panes; e ordenamos que por esta mesma vía, forma e manera, sea librado e juzgado por el alcalde de Muro el daño que fuere fallado en los panes e viñas del término de Enciso e de sus aldeas, quando uviere sospecha algún vezino de la dicha villa de Enciso e de sus aldeas e lo fizieron, dañaron e comieron, ganados de los vezinos de Muro e de Entrambasaguas. 
Otrosí ordenamos que quando acaeçiere que algunos de los dichos ganados de los vezinos de la dicha villa de Enciso e de sus aldeas fueren tomados en qualquier de las sobredichas dehesas, que si el dehesero jurado que los tomare requiriere al pastor o pastores o señor del tal ganado que eche e saque fuera de la [tal dehesa el gana-]do que assí tomare, que sea tenudo el pastor o señor del dicho ganado de lo sacar e echar fuera luego de la dicha dehesa, e que salga de tal manera commo ganado que va en [cañada; e, si lo non quisi-]ere fazer, que lo pueda tomar luego otra vegada e llevarle la dicha pena.

Otrosí ordenamos que cada uno de los dichos concejos de Enciso e Muro sean tenidos [de poner y pongan por]el mes de enero en cada año ocho omes buenos por deheseros jurados, para guardar los términos y dehesas y las otras cosas que son entre los dichos conçejos or[-denadas y acostumbradas de se] guardar, según las ordenancas que entre los dichos concejos son; e que los tales deheseros jurados sean hombres de buena fama e sin sospecha; e estos dichos dehe[-seros jurados que puedan pren-]dar a qualquier e a qualesquier que fallaren que deven las dichas penas; e qualquier que la prenda amparare e defendiere que caya en pena del doblo; e [que si el jurado se fuere] querellar a los ofiçiales del logar donde fuere vezino el que assí amparare la prenda, que los ofiçiales del tal lugar sean tenidos de le entregar la dicha pena con el [doblo de los bienes del rebelde, diz-]iendo el jurado sobre juramento que hizo que lo tomó el coto e le fue defendida la dicha prenda; e que el carnero que assí fuere tomado por prenda por los [cotos sobredichos qu-]e non sea mansso nin murueco, ni castrón nin çencerrado; e si destos tomare que pierda su derecho que ý avía.

Et nos, los dichos conçejos, e cada uno de nos, e alcaldes e oficiales e omes bu[-enos dell-]os, dezimos e queremos que refiriéndonos a la ordenanca de hermandad susoescripta e a cada cosa e parte della, e aviéndola por justa e buena e común e razonable, que la aprovamos [e loamos] según que se en ella e por ella contiene, e la avemos por rata e grata e firme e valedera por bien fecha para agora e para en todo tiempo, e dezimos e queremos que, puesto que algún defecto fuesse en ella de partes o de otra qualquier causa, que de nuestra cierta sciencia e sabiduría, que lo suplimos; e aviéndola por bien fecha e acabada con todas las solemnidades que se requieren.

Otrosí dezemos e queremos e tenemos por bien que por esta presente ordenança de hermandad e composiçión non queremos nin entendemos de reprovar nin reprovamos, nin impugnar nin impugnamos, la ordenanca e composición de hermandad que entre nos, los dichos concejos está hecha antes desta e signada de los signos de Domingo Fernández e Fernán Martínez, e Martín Fernández, nuestros escrivanos e notarios públicos, antes la aprobamos, loamos e alavamos, et dezimos e queremos que por la una ordenança non se cause derogación a la otra.

E para todas estas dichas cosas e cada una dellas tener e guardar e cunplir, obligamos todos nuestos bienes e de qualquier de nos e de nuestros vezinos, assí muebles commo raýzes, avidos e por aver; e qualquier de nos, los dichos concejos, que fuéremos o viniéremos contra todo lo sobredicho o contra parte dello en algún tienpo, que cayamos en pena de çien florines de buen oro e de justo peso del cuño del regno de Aragón, por cada vegada; et que esta dicha pena que sea para el otro concejo, e que pueda prendar por ella en bienes del dicho concejo que cayere en la dicha pena sin ser sobrello requeridos, ni citados nin demandados; et la pena pagada, o non pagada, que siempre esta dicha ordenança e composición finque firme e valedera, según que se en ella se contie- 
ne, para agora e para siempre jamás, por nos e por los que serán después de nos vezinos e moradores en los dichos logares.

E porque esto es verdad e no venga en duda, pidimos e rogamos e mandamos nos, el dicho concejo, alcaldes, oficiales e omes buenos de Muro, sobredichos, a vos, Fernán Ruiz, nuestro escrivano público, e a vos, Diego Fernández de Enciso, escrivano de nuestro señor el rey, que estades presentes, que escrivades o fagades escrevir desto que sobredicho es dos cartas, tal la una commo la otra, para amos los dichos conçejos, e las signedes de vuestros signos.

Et otrosí mandamos nos, el dicho concejo de Muro, a nuestro juez que tiene nuestro sello, que selle las dichas cartas con el dicho nuestro sello, e a los presentes rogamos que sean dello testigos.

Et otrosí nos, el dicho concejo, alcaldes e oficiales e omes buenos de la dicha villa de Enciso sobredichos, pidimos, rogamos e mandamos a vos, Fernán Ximénez e Garci Martínes, nuestros escrivanos públicos, que estades presentes, que escrivades o fagades escrevir desto que sobredicho es dos cartas, tal la una commo la otra, para nos, ambos los dichos concejos, e las signedes de vuestros signos.

Et otrosí mandamos nos, el dicho concejo, alcaldes, oficiales e omes buenos de la dicha [fol. v.] villa de Enciso, a nuestro juez que tiene nuestro sello, que selle las dichas cartas con el dicho nuestro sello; e, a los presentes, rogamos que sean dello testigos.

Fecha e otorgada fue esta carta por los dichos concejos en la manera que dicha es, en los logares sobredichos, a veynte e siete días del mes de setienbre, año del nascimiento del nuestro salvador Ihesu Christo de mil e quatrocientos e veynte e dos años.

Testigos que fueron presentes, Ilamados e rogados en el dicho conçejo de Muro, Johan López de Arellano, vezino de Cervera, escudero de Johan Remírez de Arellano, señor de la dicha villa de Muro, e Pascual Abbad, cura, e Fernán Sánchez del Campo, e Goncalo Martínez e Martín Abbad el Moço, e Martín de Alcaraz e Pero Gil, todos vezinos de la dicha villa de Muro; e Fernán Martínez, cura, e Fernán Ximénez, escrivano, e Johan Ximénez e Johan Castiello de Navalsaz, vezinos de la dicha villa de Enciso.

Testigos que fueron presentes, Ilamados y rogados en el dicho concejo de Ençiso, el dicho Johan López de Arellano e Rodrigo Ramo, alcalde, e Ruy Díaz, vezinos de Muro, e Fernán Martínez, cura, e Martín Fernández de Torquemada, e Pero Fernández Ferrero, e Johan Goncalo e Pedro de Portillo, e Lope Martínez e Johan Cogedor, e Pero García de Oceta e Pero Márquez, e Fernán Martínez de la Caleja, vezinos de la dicha villa de Enciso.

E yo, Diego Fernández de Enciso, escrivano de nuestro señor el rey e su notario público en la su corte e en todos los sus regnos, fui presente a todo lo en esta carta contenido en uno con los dichos testigos en el dicho conçejo de Muro, e por su ruego e mandado, la fize escrevir e fiz aquí este mio sig-(signo)-no en testimonio de verdad.

Diego Fernández (rubricado).

E yo, Ferránt Ruiz, escrivano público de la villa de Muro e su tierra, fui presente a todo lo en esta carta contenido con los dichos testigos en el dicho conçejo de Muro, por su ruego e mandado la fiz escrevir e fiz aquí este mio sig-(signo)-no en testimonio de verdad.

Ferránt Ruiz (rubricado).

E yo, Garci Martínez, escribano público sobredicho, fui presente a todo lo en esta carta contenido en uno con los dichos testigos en el dicho conçejo de Ençiso, e por 
su ruego y mandado la fiz escrevir e fiz aquí este mio sig-(signo)-no en testimonio de verdad.

Garci Martínez (rubricado).

E yo, Fernán Ximénez, escrivano público sobredicho, fui presente a todo lo en esta carta contenido con los dichos testigos en el dicho conçejo de Ençiso, e por su ruego y mandado, la fiz escrevir et fiz aquí este mi sig-(signo)-no en testimonio de verdad.

Fernán Ximénez (rubricado).

\section{6}

1422, octubre, 25. ILLESCAS.

Diego Pérez Sarmiento, repostero mayor del rey y señor de la villa de Enciso, aprueba los acuerdos alcanzados por los concejos de Enciso y Muro de Aguas en septiembre de este año.

Archivo Municipal de Enciso. Perg. (A).

Archivo Municipal de Muro de Aguas (B). Signat. P010/01. Cuadernillo de 15 hojas de papel de $220 \times 160 \mathrm{~mm}$. aprox.; falta la $1^{\text {a }}$ de ellas; fols. r. Traslado, realizado el 11 de noviembre de 1522, por Diego Martínez, escribano público de la villa de Enciso, y por Pedro Ramo, escribano público de la villa de Muro de Aguas, de las cartas de hermandad suscritas por los concejos de Enciso y Muro de Aguas en 1373 y 1422 (B).

Archivo Municipal de Enciso (C). Signat. ENCI005/07. Libro de traslados de concordias y ordenanzas. Fol. 35v. Muro.

Et yo, Diego Pérez Sarmiento, repostero mayor del rey, señor de la dicha villa de Ençiso, otorgo e conosco que hé por rata e grata e firme esta dicha hermandad que es entre los dichos concejos; e prometo de nunca ir nin venir contra ella nin contra parte della, yo ni otri por mí, en algún tiempo, so obligación de todos mis bienes muebles e raýzes, avidos y por aver; et de no pedir restitución in integrum ni en parte; e, porque esto es verdad, screví aquí mi nonbre en esta carta, e mandela sellar con mi sello pendiente.

Fecha en Yliescas, veynte e çinco días de octubre, año en esta dicha carta contenido.

Diego Pérez (rubricado).

\section{7}

1422, SAN PEDRO DE YANGUAS.

Juan Ramírez de Arellano, Señor de los Cameros y de la villa de Muro de Aguas, aprueba los acuerdos alcanzados por los concejos de Enciso y Muro de Aguas en septiembre de este año.

Archivo Municipal de Enciso. Perg. (A). 
Archivo Municipal de Muro de Aguas (B). Signat. P010/01. Cuadernillo de 15 hojas de papel de $220 \times 160 \mathrm{~mm}$. aprox.; falta la $1^{\text {a }}$ de ellas; fols. r.- v. Traslado, realizado el 11 de noviembre de 1522, por Diego Martínez, escribano público de la villa de Enciso, y por Pedro Ramo, escribano público de la villa de Muro de Aguas, de las cartas de hermandad suscritas por los concejos de Enciso y Muro de Aguas en 1373 y 1422 (B).

Archivo Municipal de Enciso (C). Signat. ENCI005/07. Libro de traslados de concordias y ordenanzas. Fol. 35v. Muro.

Yo, Johan Remírez de Arellano, Señor de los Cameros e de la dicha villa de Muro e de Entrambasaguas, otorgo e conosco que hé por rata e grata e firme [e] estable e valedera esta dicha hermandad que es entre los dichos concejos; e prometo de nunca ir nin venir contra ella nin contra parte della, yo ni otri por mí, en algún tiempo, so obligación de todos mis bienes muebles y raýzes, avidos y por aver; e de non pidir restitución in integrum, en todo ni en parte; e, porque esto es verdad, screví aquí mi nonbre en esta carta, e mandela sellar con mi sello pendiente.

Fecha en Yanguas.

Juan Remírez (rubricado).

8

1450, septiembre, 29. EL OCIJO (mojonera de Muro de Aguas y Préjano).

Concordia suscrita por los concejos de Muro de Aguas y de Préjano en 1450.

Archivo Municipal de Muro de Aguas. Signatura P10/03. Un cuadernillo de papel de 14 folios de $210 \times 150 \mathrm{~mm}$. cada uno, aprox; fols. 2v.-8v. Traslado notarialmente compulsado sacado en la villa de Préjano por Álbaro de Hudobro, escribano de la dicha villa, el 29 de septiembre de 1545; a petición de Pero Ximénez, procurador de la villa de Muro de Aguas (B).

Archivo Municipal de Muro de Aguas. Signatura P10/05. Libro de papel con guardas de pergamino con la leyenda: Concordias de Muro e su barrio; y otras. Cuadernillo de papel con la leyenda: Concordias con las villas comarcanas. Fols. 9-19 (C).

Archivo Municipal de Muro de Aguas. Signatura P10/02. Real Ejecutoria del emperador Carlos I dada en Valladolid, a 6 de julio de 1555; fols. 12r.-16v. (D).

[fol. 2v.] Sepan quantos esta carta vieren como el conçejo de Muro de Trambasaguas e commo nos, el conçejo de Préxano, siendo ayuntados en la sierra donde dizen Hoçijo, en el lugar de onde se parten los términos de nos, los dichos conçejos, otorgamos e conosçemos que por razón de quitar de nos contiendas e daños, e males e peleas que se podrían acaebçer entre nos, los dichos conçejos; e por razón de los tajos e pastos, e leña e fusta de los montes, de los cotos que an menester mejorar, e por allegar en tal manera que todos fuésemos abenidos en bien e lo pudiésemos bien pasar los unos con los otros, e las buenas amiganças e amoríos levar cabo adelante; e por vivir en paz y sosiegoen 
todos tienpos del mundo para sienpre jamás, hordenamos buena e leal hermandad en esta manera que se sigue:

Primeramente que qualquier vezino o vezinos de Muro e de Entrambasaguas que an heredad en término de Préxano, e los vezinos de Préxano que ovieren heredad en término de Muro y de Entramasaguas, así por conpra como por herençia o por casamiento, que qualquier que la oviere en los dichos términos que pasen conpuesta del un lugar al otro, cada uno como tubiere, salvo del que se fuere de morada del un lugar al otro, que paguen por lo que tubiere.

Otrosí en razón de las biandas que los de la villa de Muro y de Entramasaguas que las puedan conprar en la villa de Préxano y en su tér-[fol. 3r.]-mino y sacarlas y llevarlas así como qualquier vezino de Préxano, tanto por tanto; así pan e vino e carne, muerta y viba, e todas las otras cosas que se pueden conprar e bender.

Otrosí los vezinos de Préxano puedan conprar e sacar e llevar todas las dichas viandas que sobredichas son de la dicha villa de Muro e de Entramasaguas o de su término sin pena alguna.

Otrosí [si] vos, el dicho conçejo de Muro y de Entramasaguas oviéredes menester acorro de conpaña que nos, el dicho conçejo de Préxano, seamos thenudos de vos acorrer con veynte y çinco honbres a donde fuéremos Ilamados de vos, el dicho conçejo de Muro.

Otrosí si vos, el dicho conçejo de Préxano, oviéredes menester acorro de conpaña que nos, el dicho conçejo de Muro y de Entramasaguas seamos tenudos de vos acorrer con quinze honbres a donde fuéremos Ilamados de vos, el dicho conçejo de Préxano; y, a esta tal gente, quel conçejo por quien fueron Ilamados les fagan la costa.

Otrosí hordenamos nos, los dichos conçejos, que los vezinos de la villa de Muro y de Entramasaguas que puedan cortar leña y ramón y leña verde y seca del término de Préxano sin coto e sin caloña, e que puedan hazer matança de ramón y de caxigo y de revollo, no cortando por el pied ni por cornal, salbo por las çimas; e que dexe poda-[fol. $3 \mathrm{v}$.$] -dizo en la dicha matança; e si cortare por el pied que aya de coto quatro maravedís;$ y por el cornal, no dexando podadizo, dos maravedís; y este mesmo coto ayan los de Préxano en término de Muro y de Entramasaguas; y que puedan cortar y llevar el dicho ramón y leña verde y seca del dicho término de Muro y de Entramasaguas y hazer matança de ramón e de caxigo y de revollo a qualquier ganado sin coto y sin caloña, no cortando por el pied ni por cornal; y si cortare por el pied o por cornal, no desando podadizo, qua ayan la caloña sobredicha.

Otrosí toda fusta que fuere menester para aradro, o a hazer casa, e para çellos de cubas e tinos y para las heras, que sea franco todo tajo para todos sin coto e sin caloña de los unos a los otros en los dichos términos.

Otrosí hordenamos que las enzinas que las ayan sueltas del un conçejo y al otro y del otro al otro desde el día de Sant Martín adelante, qualesquier de los dichos conçejos que antes las cogiere en cada un año, que aya de pena cada persona un maravedí. Esto se entienda en los términos que podemos pasçer así los unos como los otros. E qualquier que pasare a coger las dichas enzinas allende de los dichos términos que podemos paçer aya cada persona çinco blancas; y las landes que sean sueltas para quien las cogiere de los unos [fol. 4r.] a los otros. E si antes del dicho día de Sant Martín abarearen enzinas a puercos o a puercas, o a otro ganado qualquier que aya de coto cada res dos dineros. 
Otrosí la cabaña de las obejas e cabras de qualquier vezino de Muro e de Entramasaguas que yoguiere de noche o paçiere después del sol entrado, o antes que salga, en término de Préxano, que aya [de pena] un carnero y que aya de coto ocho maravedís; y si el pastor diere prenda que valga diez maravedís quel jurado no lieve el carnero; e si, por aventura, el pastor defendiere el carnero e no lo quisiere dar quel jurado baya al lugar de onde fuere el ganado al alcalde [e] que le entregue con el doblo el coto sobredicho; e si el alcalde no lo quisiere entregar quel querelloso se pueda entregar del coto sobredicho; e si el pastor no diere prenda quel jurado tome el carnero o lo tenga hasta terçero día; e si no lo quitare fasta el terçero día quel jurado lo pueda matar e lograr sin pena alguna; e si el pastor metiere el ganado adelante de como está tasado por do pueden paçer los dichos conçejos quel jurado de qualquier de los dichos conçejos le pueda tomar carnero sin pena e lo pueda matar; e si, por aventura, alguno entrare en deesa acostunbrada después que fuere echada por los dichos conçejos, del primero día de março fasta el día de Santa María de meytad de agosto, así en la yerba como en el pan, que aya el jurado el carnero [fol. 4v.] si fueren de treynta arriba e, de treynta a yuso, dos reses un dinero de la moneda que corriere; y esto se entiende a todo ganado menudo, obejas y cabras.

Otrosí los puercos que ayan de coto çinco dineros fallándolos en la mies, de treynta a yuso e, de treynta arriba, que aya carnero; y el carnero que aya veynte y çinco maravedís de pena; e quel jurado lo tenga terçero día; e, si no biniere a lo quitar dentro en el dicho terçero día, quel jurado lo pueda gozar. E este coto que ayan del día que la pieça fuere senbrada fasta el primero día de março; e, después del primero día de março adelante, que aya cada puerco según el otro ganado menudo en los dichos términos.

Otrosí los bueys e bacas, e yeguas o vestias, de qualesquier vezinos de Muro e de Entramasaguas que yoguieren o andubieren de noche o de día en término de Préxano, del primero día de março hasta Santa María de mitad de agosto, desque fuere echada la dehesa, que aya de coto así en la yerba como en el pan cada res un maravedí; e este mesmo coto ayan los de Préxano en término de Muro e de Entramasaguas.

Otrosí si, por aventura, labraren los vezinos de Préxano en término de Muro y de Entramasaguas [y] entraren en la dehesa a paçer, que ayan [fol. 5r.] la caloña y coto como los de Muro y Tramasaguas; e si los vecinos de Muro y de Entramasaguas labraren en término de Préxano y entraren en la dehesa que ayan el mesmo coto que los de Préxano, e que los puedan así prendar cada uno en su término como a sus vezinos.

Otrosí si algún ganado bueys, o bacas e yeguas, pasaren de como está tasado adelante de los vezinos de Muro y de Entramasaguas, que aya cada una res de caloña çinco dineros; y este mesmo coto ayan los bueys e bacas o vestias que pasaren de como está tasado en término de Muro e de Entramasaguas e de Préxano, del un término al otro de los dichos conçejos.

Otrosí si algunos vezinos de qualesquier de nos, los dichos conçejos, traxeren ganados algunos ajenos con los nuestros que puedan los deheseros de qualesquier de los dichos conçejos tomar carnero o carneros en las cabañas de onde ovieren sospecho que anda ganado ajeno, cada uno en su término; salvo si, por aventura, algún vezino de nos, los dichos conçejos, tobiere moço a soldada, que pueda traer el moço con las de su amo fasta treynta reses; y éstas que no sean carnereadas de día ni de noche mas que ${ }^{56}$ las de su amo.

56. Sino como. 
Otrosí, si los deheseros ovieren sospecho que algún ganado ajeno anda en qualquier de las cabañas, [fol. 5v.] que le puedan demandar jura según forma de derecho antel alcalde del lugar donde fuere llevado el carnero; $y$, si el pastor no quisiere hazer la jura, que pierda el carnero que así fuere tomado y que lo guarden los deheseros del día que lo tomare hasta nueve días; y, si el pastor no quisiere hazer la jura fasta los nueve días, que los jurados puedan gozar el carnero o carneros que así tomaren.

Otrosí que qualquier ganado bacuno, o yeguas o bestias, que entraren en el pan de qualquier de los dichos lugares, que ayan de coto cada res fasta el primero día de março dos dineros.

Otrosí qualquier ganado menudo que entrare en el pan ante de março que aya de coto cada res un dinero; e de treynta arriba carnero.

Otrosí las dehesas que cada uno de nos, los dichos conçejos, echáremos cada uno en su término, como son acostumbradas, que seamos thenudos a las guardar los unos a los otros, del primero día de março hasta el día de Santa María de meytad de agosto; y qualquier que en ella entrare que aya el coto sobredicho.

Otrosí qualquier ganado menudo que entrare en el pan en qualquier término de nos, los dichos conçejos, que aya de coto cada res un çelemín del pan questubiere el senbrado donde se hiziere el daño, o el apreçia-[fol. 6r.]-miento qual más quisiere el dueño.

Otrosí si bueys o bacas o bestias de los vezinos de los dichos conçejos entraren en el pan de qualquier de los términos que aya de coto cada res tres çelemines del pan que fuere el senbrado, o el apreçiamiento según quel dueño quisiere, cuyo fuere el pan.

Otrosí, en razón de las maquilas sobredichas, que fasta el primero día de março pague la meytad; fasta este dicho día que saque la madre al hijo que mamare y no oviere año; esto sea por todo ganado.

Otrosí, en razón de los [cotos] que sobredichos son, que qual o qualesquier vezino o vezinos de los dichos lugares que fueren rebeldes de no pagar, o defendiere la prenda a los jurados, que los ofiçiales que fueren en aquel tienpo en qualquier de los dichos lugares sean thenudos, so la dicha pena que en esta carta será contenida, de les dar y entregar de todo lo que asý fuere tomado con el doblo del rebelde en el lugar donde fuere dada la querella.

Otrosí si, por aventura, en qualquier de los dichos lugares o en sus términos, acaesçieren o vinieren o estasen alguna persona o personas a fazer mal, o daños o robos, e de aquéllos se presumiese aver algún resapio, que qualquier persona de los dichos conçejos pueda dar quexo de la tal persona sin pena singuna, [fol. 6v.] e el alcalde e ofiçiales que fueren que sean thenudos de lo tomar preso, e no lo suelten hasta ser bisto por los dichos conçejos; e si en culpa lo hallaren que lo executen o suelten a una concordia.

Otrosí que vos, el conçejo de Muro e de Entramasaguas, podades paçer las yerbas e veber las aguas con vuestros ganados con sol, guardando pan e vino e las dehesas que fueren echadas, como dicho es, en el término de Préxano, sueltamente de vuestro término al nuestro, por el çerro de çima Navagalindo, e agua vertiente al Cuerno Vallota, y por la Peña de Vallota a la parte Foçijo, e por la peña abaxo a las Fuentes de Mingo Pardo y al pedaço de Juan Ximénez questá en la sierra, y sierra adelante por donde se desbía la dehesa de ençima de Arapita, e como ba la carrera para Santa María Madalena 
para los Çirujuelos y al RegajoTotico, de vuestro término al nuestro; e vos, el conçejo de Préxano, que podades paçer las yerbas y veber las aguas de vuestro término al nuestro, todo Totico y el Hombriallega y a los Angostiellos, y por el cabeço de sobre laldea y al Collado Micolayo, y por el sendero que va a los Villares y por la Carrera de Arne-[fol. 7r.]-do fasta çima Nabaltello ${ }^{57}$ y al Pozo Juan Nabarro, y a la peña del Prado de Navatiello como monta todo el prado.

Otrosí los jurados que fueren puestos en cada logar que les tomen jura en cada conçejo y, desque así ovieren jurado, sean creýdos en su ofiçio por el dicho de su palabra, confirmando la jura que fizieron.

Otrosí hordenamos entre nos, los dichos conçejos, que ninguno ni algunos no seamos tenudos a ninguno ni alguno vezino ni vezinos, por paxto ni por yazijas en los términos de nos, los dichos conçejos, de qualquier de nos, salvo por morada en qualquier de los dichos lugares, afumando casa donde rescibió la dicha vecindad.

Y a todas estas cosas y a cada una dellas que sobredichas son queremos que sean firmes y valederas para agora y todos tienpos del mundo, e de nunca yr ni benir contra ella ni contra parte dello en ninguna manera; e qualquier de nos, los dichos conçejos Muro e Tramasaguas e Préxano, que no guardáremos todas las cossas que en esta carta son escriptas e cada una dellas, [e] las quebrantásemos en todo o en parte dello, que cayamos en pena de diez mil maravedís el conçejo que no guardásse todas e cada unas cosas que en esta carta son escriptas; e desta [fol. 7v.] pena sobredicha nos, los dichos conçejos, damos poder a los ofiçiales que fueren por tienpo que puedan entregar y entreguen, cada uno en sus lugares, de la dicha pena al conçejo de quien no fueren guardadas estas cosas y cada una dellas, de aquél o aquéllos que lo ovieren de aver e de recavdar por él; e si, por aventura, los ofiçiales que fuesen por tienpo no quisiesen entregar la dicha pena en bienes del conçejo que en la dicha pena cayere, desde el día que les fuere requerido fasta veynte días primeros siguientes, que deste plazo en adelante quel conçejo que obiere de rescebir la pena, o aquél o aquéllos que lo ovieren de recavdar por él, que se puedan entregar por sí de los bienes del conçejo que en la dicha pena cayere; e puesto que la pena sea pagada o non pagada que todo quanto en esta carta se contiene sea firme y valedero para agora y para siempre jamás.

Otrosí que quando algunas cosas fueren menester de librar por la yunta entre los dichos conçejos que lo hagan saver por carta el un conçejo al otro, que salgan a yuntas allí adonde lo an [de] uso e costunbre; e qualquier que fuere revelde e no quisiere salir a la yunta que [fol. 8r.] caya en pena de veynte maravedís a la parte que biniere; e esta pena que la enbíen demandar una bez a los que en ella cayeren e, si no se la pagaren del día que les fuere demandada fasta otro día, que ellos por sí se puedan entregar.

E porquesto sea firme y valedero, según que sobredicho es, e cada una cosa, mandamos a vos, Martín Martínez e Juan Ramo, escribanos públicos de los dichos lugares que presentes estades, que fagades o mandedes fazer dos cartas, tal la una como la otra, e las sygnedes de vuestros signos, e dedes sendas a los dichos conçejos en las quales nos, los dichos conçejos, pornemos nuestros sellos de çera pendientes.

57. En D: Nabalterio. 
De lo qual rogamos a Juan Ximénez, mayordomo, y a Martín Garrido, alcalde, y a Sancho López e a Juan Garrido, vezinos de Préxano, e a Pero López e a Rudíaz, y a Gil Ximénez de la Plaça e a Pero Martínes, juez, e Llorente, vezinos de Muro e de Entramasaguas, que sean dello testigos.

Fechas y otorgadas fueron estas cartas encima de Foçijo, onde se parten los términos de nos, los dichos conçejos, a veynte e nueve días del mes de setienbre, año del nasçimiento de nuestro Salvador Ihesu Christo de mill y quatoçientos y çinquenta años.

Otrosí qualquier ganado mayor de Muro e de Entramasaguas que yoguiere de noche en tér-[fol. 8v.]-mino de Préxano, siendo dehesa, que aya de coto cada una res un dinero; e este mesmo coto ayan los de Préxano en término de Muro y de Entramasaguas.

Otrosí en razón de las maquilas y daños que de suso es dicho que aya plazo y término de las pagar fasta el día de San Gil, qualquier que las oviere de pagar en los dichos conçejos.

E yo, el diccho Martín Martínez, escribano público de la dicha villa de Préxano, fuy presente a todo lo que dicho es en una con el dicho Juan Ramo, escribano, y con los dichos testigos; e a otorgamiento de los dichos conçejos esta carta escreví e, por ende, fiz aquí en ella este mio sygno a tal en testimonio de verdad.

Martín Martínez.

E yo, el dicho Juan Ramo, escribano público de la dicha villa de Muro, fuy presente a todo lo que dicho es con el dicho Martín Martínes, escribano, e los dichos testigos; e a otorgamiento de los dichos conçejos esta carta fiz escrevir e, por ende, fiz aquí en ella este mio sygno a tal en testimonio de verdad.

Juan Ramo.

1451, enero, 20.

Juan Ramírez de Arellano II, Señor de los Cameros, aprueba y se compromete a respetar los acuerdos alcanzados por los representantes del concejo de Muro de Aguas, perteneciente al Señorío de los Cameros, con los del concejo de Préjano, en la junta que han celebrado el 29 de septiembre de 1450, a condición de que Diego González de Toledo, señor de la villa de Préjano, haga lo mismo.

Archivo Municipal de Muro de Aguas. Signatura P10/03. Un cuadernillo de papel de 14 folios de $210 \times 150 \mathrm{~mm}$. cada uno, aprox; fols. 8v.-9r. Traslado notarialmente compulsado por Álbaro de Hudobro, escribano público de Préjano, el 24 de noviembre de 1545, en dicha villa; fue sacado a petición de Pero Ximénez, procurador de la villa de Muro de Aguas (B).

Archivo Municipal de Muro de Aguas. Signatura P10/02. Real Ejecutoria del emperador Carlos I dada en Valladolid, a 6 de julio de 1555; fols. 16v. (C).

Archivo Municipal de Muro de Aguas. Signatura P10/05. Libro de papel con guardas de pergamino con la leyenda: Concordias de Muro e su barrio; y otras. Cuadernillo de 
papel con la leyenda: Concordias con las villas comarcanas. Fols. 19r. Traslado del anterior de 1545 (D).

[fol. 8v.] Yo, Juan Remírez de Arellano, Señor de los Cameros, vista esta carta de hermandad y conparaçiones suso contenida, a petiçión de los conçejos de Muro e Préxano suso nonbrados, que a mí ynbiaron sus procuradores, confírmola según por ella se contiene; e apruevo y avtorizo lo en ella escripto en la [fol. 9r.] mejor forma que puedo y debo de derecho, con esta condiçión: quel dotor Diego Goncález de Toledo, que al presente es señor de la dicha villa de Préxano, por sí y por sus suçessores, firme e avtorize como yo esta dicha escriptura, ca él no lo queriendo así fazer, no la é por confirmada ni autorizada. En fe de lo qual firmé aquí mi nonbre.

Que fue fecha en la dicha villa de Muro, a veynte días del mes de henero, año del nasçimiento de nuestro señor Ihesu Christo de mill y quatroçientos $\mathrm{y}^{58}$ çinquenta y un años.

Juan Remírez.

\section{0}

1490, julio, 11.

Traslado notarialmente compulsado de los acuerdos de la yunta celebrada entre los concejos de Muro de Aguas y Enciso de 29 de septiembre de 1373, pedido por sus representantes en la de este año para revalidarlos.

Archivo Municipal de Enciso (B). Signat. ENCI005/07. Libro de traslados de concordias y ordenanzas. Fol. 25r.-25v. Muro.

[fol. 25r.] Lunes, honze días de jullio, año del nasçimiento de nuestro señor Ihesu Christo de mill e quatroçientos e noventa años.

Este dícho día, seyendo en yunta los conçejos de Muro e de Ençiso e de Muro de Entramasaguas, llamados por sus cartas de según que lo han de uso e de costunbre cerca del nozedo que dizen de Totico, que [es] entre los términos de los dichos logares, en el mojón donde parten los términos; nombradamente, de la parte del dicho conçejo de Ençiso, por yunteros: Diego Álbarez, cura, e Domingo Hernández de Portiello, alcalde, e Juan Martínez Christóval, e Juan Ferrándes Ferrero, juez, e Domingo Herrándes e Martín Hernández, escribanos públicos del dicho logarde Ençiso; e de la parte del dicho conçejo de Muro, por yunteros: Pero Sánchez, alcalde, e Iváñes Domingo e Fernán Martínes, cura e escrivano público, e Martín Hernández el Coxo, e Martín Abad e Martín, hijo de Martín de Alcaraz, todos vezinos del dicho lugar de Muro.

Dixeron que por quanto los dichos conçejos de los logares de Ençiso e Muro avíen sus usos e costunbres usados de los quales usaron siempre hasta aquí, e abían sobrello

58. Tachadas las palabras: un años. 
sus cartas e hordenanças signadas e selladas con sus sellos gran tiempo abía; e que por razón que las dichas cartas fueron escritas entonçes en papel e agora fallaban que se molían entre sí, e que se rasguaban á ${ }^{59}$ luengo tiempo e que se podrían perder por esta razón, e que no se podrían tan bien leer ni declarar como hera menester; e porque avían voluntad que las dichas ordenanças fuesen firmes para siempre e las buenas amiganças no se perdiesen, e no aviendo voluntad de las desatar ni quebrantar, en todo ni en parte por alguna manera ni razón, mas aviéndolas por estables e por firmes en la manera que fueron fechas ante al tiempo que las ordenaron, e por que no se moliesen ni perdiesen por delongança de tiempo, [fol. 25v.] e que mandavan e rogaban a nos, los dichos Domingo Hernández e Martín Fernández, e Hernán Martínes, escribanos públicos de los dichos conçejos e que estábamos presentes, que las escreviésemos agora otra vez en pargamino de cuero en la guisa e manera que fueron escritas antes en papel, e no menguando cosa alguna de las que fuere[-n] escritas en las cartas de las dichas ordenanças de los dichos usos e costunbres que usaron hasta aquí, e las signásemos con nuestros sygnos en manera que hiziesen fe; e a los que tienen los sellos de los dichos conçejos porque fuesen firmes e no viniesen en dubda; el tenor de las quales dichas cartas de ordenanças que fueran fechas ante los dichos conçejos es como se sigue:

Aquí traslada el doc. 1 (1373, septiembre, 29).

59. Hacía. 